\title{
Margins of International Banking: Is there a Productivity Pecking Order in Banking, too?
}

\author{
Claudia Buch \\ Cathérine Tahmee Koch \\ Michael Kötter
}

\author{
CESIFO WORKING PAPER NO. 2891 \\ CATEGORY 7: MONETARY PoliCy AND InTERnAtIONAL FINANCE \\ DECEMBER 2009
}

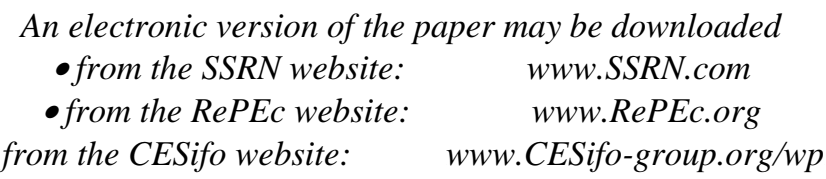




\title{
Margins of International Banking: Is there a Productivity Pecking Order in Banking, too?
}

\begin{abstract}
Modern trade theory emphasizes firm-level productivity differentials to explain the crossborder activities of non-financial firms. This study tests whether a productivity pecking order also determines international banking activities. Using a novel dataset that contains all German banks' international activities, we estimate the ordered probability of a presence abroad (extensive margin) and the volume of international assets (intensive margin). Methodologically, we enrich the conventional Heckman selection model to account for the self-selection of banks into different modes of foreign activities using an ordered probit. Four main findings emerge. First, similar to results for non-financial firms, a productivity pecking order drives bank internationalization. Second, only a few non-financial firms engage in international trade, but many banks hold international assets, and only a few large banks engage in foreign direct investment. Third, in addition to productivity, risk factors matter for international banking. Fourth, gravity-type variables have an important impact on international banking activities.
\end{abstract}

JEL-Code: F30, G21.

\author{
Claudia Buch \\ University of Tübingen \\ Mohlstrasse 36 \\ Germany-72074 Tuebingen \\ claudia.buch@uni-tuebingen.de
}

Cathérine Tahmee Koch

Institute for Empirical Research in

Economics

University of Zurich

Zuerichbergstrasse 14

Switzerland - 8032 Zurich

catherine.koch@iew.uzh.ch
Michael Kötter

Faculty of Economics and Business

University of Groningen

Nettelbosje 2

9747 AE Groningen

The Netherlands

m.koetter@rug.nl 
This paper was partly written during visits of the authors to the research centre of the Deutsche Bundesbank. The hospitality of the Bundesbank, as well as access to its bank-level financial accounts and External Position Report database, are gratefully acknowledged. We have benefited from comments received from the Bangor Business School seminar series, the $5^{\text {th }}$ Macroeconomic Research Meeting (MaRem), the University of Amsterdam, the University of Bonn, the CEPR-GIST conference held in Milano, and the seminar series at Deutsche Bundesbank. In particular, we are grateful to Yener Altunbas, Stefan Boes, Jörg Breitung, Wouter den Haan, John Goddard, Heinz Herrmann, Mathias Hoffmann, Thilo Liebig, Monika Merz, Phil Molyneux, Esteban Prieto, Ward Romp, Winfried Rudek, Jochen Schanz, Kevin Staub, John Thornton, Neeltje van Horen, and John Williams for their most helpful discussions and suggestions. Lena Tonzer provided efficient research assistance. Financial support from the National Science Foundation in the Netherlands (NWO) (M. Koetter), the Foundation "Stiftung Geld und Währung" (C. Koch), and the EFIGE project financed by the European Commission (SSH-2007-1.2.1) is gratefully acknowledged. All errors and inconsistencies are solely our own responsibility. 


\section{Motivation}

Recent advances in international economics provide fairly good information about the internationalization patterns of firms. Empirically, larger and more productive firms are more likely to export and engage in foreign direct investment (FDI) than are smaller and less productive firms (see Helpman et al. 2004; Bernard et al. 2006, 2007; Tomiura 2007; Yeaple 2009). The explanation for these stylized facts involves the interaction between firm-level productivity and the costs of market entry (Melitz 2003; Helpman et al. 2008). Domestic fixed costs are lower than the costs of exporting, which are lower than the costs of FDI. Exporting also entails higher variable costs. Thus, firms self-select into different modes of entry, realizing that the higher the fixed costs of a mode of entry, the higher is the required productivity, which results in a "pecking order of productivity."”

Yet we know relatively little about the internationalization of services firms and, in particular, banks. ${ }^{2}$ Therefore, we investigate whether banks differ: To what extent are the internationalization decisions of banks determined by productivity, which factors affect the extensive (foreign investment decision) and intensive (volume of activities) margins, and which factors affect particular modes of activities? In contrast with prior research (e.g., Berger et al. 2003; Ruckman 2004; Buch and Lipponer 2007), ${ }^{3}$ we explicitly model bank productivity and distinguish among different modes of foreign activities (international assets, foreign branches, foreign subsidiaries). In addition, we explicitly distinguish the extensive from the intensive margin.

Our study goes beyond previous evidence in four regards. First, we use a novel and comprehensive dataset that provides detailed information about the internationalization choices of German banks. The “External Position Report” provided by Deutsche Bundesbank contains information about the international assets of German banks, their foreign branches, and their foreign subsidiaries, year-by-year and country-by-country. There have been no minimum reporting thresholds since 2002. Therefore, we have detailed information about all domestic and internationally active banks. We find that, in contrast with non-financial firms,

\footnotetext{
${ }^{1}$ In international finance literature, the term "pecking order” also describes the structure of different types of international capital flows (Daude and Fratzscher 2008).

${ }^{2}$ Bonfiglioli (2008) provides country-level evidence that financial integration reflected in liberalization spurs total factor productivity in the economy but does not analyze the specific role of banks.

${ }^{3}$ Goldberg (2004) discusses the links between literature on financial and non-financial firms' FDI, with a focus on the impact on developing countries. Cetorelli and Goldberg (2008) show how differences in the degree of internationalization of banks can have implications for the effects of monetary policy.
} 
many (small) banks hold international assets. In line with evidence for non-financial firms though, few banks have foreign affiliates.

Second, we model the self-selection of banks according to the different modes of foreign activities using an ordered probit. We enrich conventional Heckman (1979) models by including hierarchical categories in the selection equation. We also show that selection into foreign status has a significant impact on the volume of activities. Most previous studies focus on large, internationally active banks only, ${ }^{4}$ which means they neglect the selection bias inherent in heterogeneous firm (productivity) models.

Third, we take into account the differences in banks' production processes compared with those of non-financial firms. We estimate bank productivity using an empirical methodology often applied to non-financial firms, in the spirit of Levinsohn and Petrin (2003) and applied to banks by Nakane and Weintraub (2005). To estimate total factor productivity, banking studies often rely on a dual approach in which they estimate the cost or profit functions (Kumbhakar and Lovell 2000) and analyze the impact of changes in technology or factor inputs. However, this approach neglects the bias that results from the simultaneity between input choices and productivity. With our productivity measures, we find clear evidence for a productivity pecking order in international banking. Productivity is especially important for smaller banks, such as savings and cooperative banks.

Fourth, our empirical approach is motivated by a stylized model of an international bank. As in international trade literature, choosing the optimal mode of foreign activities involves a trade-off between fixed and variable costs. In contrast with international trade though, banks also take the portfolio effects of their international activities into account. The model yields testable implications for bank- and country-level factors that can determine the intensive and the extensive margin. Our empirical results support the importance of risk factors for internationalization strategies of banks.

The remainder of this article is structured as follows. In the next section, we offer some background. Section 3 contains our data and descriptive statistics, our empirical model, and our measure of bank productivity. After we provide the estimation results in Section 4, we conclude in Section 5.

\footnotetext{
${ }^{4}$ See Berger et al. (2003), Focarelli and Pozzolo (2005), or Cerruti et al. (2007).
} 


\section{Theoretical Framework}

To recognize how bank-level and host-country factors may influence international banking, consider a simple portfolio model of an international bank. We enrich a baseline closedeconomy portfolio model (Freixas and Rochet 1998) by modeling banks’ choice to service foreign markets. Banks can hold international assets through either their domestic headquarters (Mode 1) or foreign affiliates (Mode 2). ${ }^{5}$ In addition, we assume that banks invest but do not borrow abroad. ${ }^{6}$ In each period, the bank chooses its optimal portfolio structure, and the balance sheet restriction for bank $i$ is given by:

$$
W_{i}+D_{i}=L_{i}+L_{i, j}^{*}+R_{i}
$$

where $W_{i}=$ initial wealth, $D_{i}=$ domestic deposits (liabilities), $L_{i}=$ domestic loans (assets), $L_{i j}^{*}=$ foreign loans (assets) in country $j$, and $R_{i}=$ risk-free assets.

To analyze the bank's choices, consider the profits earned from two modes of foreign activities. The expected profit of a domestic bank $i$ holding international assets in country $j$ depends on the returns on its domestic and international assets minus its variable costs and the fixed costs of foreign activities:

$$
\begin{aligned}
\Pi(1)_{i j} & =\left[r_{L}-c_{i j, L}\left(\omega_{i}\right)\right] L(1)_{i}+\left[\left(1-\tau_{j}\right) r_{L, j}^{*}-c_{i j, L}^{*}\left(\omega_{i}\right)\right] L(1)_{i j}^{*}+r_{F} R(1)_{i}, \\
& -\left[r_{D}+c_{i j, D}\left(\omega_{i}\right)\right] D(1)_{i}-F(1)_{j},
\end{aligned}
$$

where $F(1)_{j}=$ the fixed costs of Mode $1 ; r_{. L}, r_{D}=$ interest rates on (risky) assets and

liabilities; $r_{F}=$ interest rate on the risk-free asset; $\tau_{j}=$ country-specific information costs that lower the return on international assets, with $0<\tau_{j}<1$; and $c_{i j, \bullet}=$ variable costs. The (1) in this equation denotes the bank's profit function under Mode 1. To model the variable costs, we use the iceberg transportation costs method known from the trade literature; the fixed and variable costs of international operations vary across host countries. We set the fixed costs of domestic operations to 0 .

\footnotetext{
${ }^{5}$ Our terminology differs from the World Trade Organization classification of foreign modes. In the language of General Agreement on Trade in Services (GATS), we focus on cross-border supply (Mode 1) and commercial presence (Mode 3). In the empirical model, we also allow for the possibility of remaining a purely domestic bank and distinguish between foreign branches and subsidiaries. Adding these options does not affect the qualitative results of the theoretical model.

${ }^{6}$ Relaxing these assumptions leaves the main qualitative results of the following analysis unaffected. We also abstract from exchange rate risk.
} 
Both raising deposits and granting loans is costly for banks, and these costs reflect the resource inputs connected to handling loan applications, maintaining a branch network, or performing payment services. We assume that banks differ with regard to their productivity $\left(\omega_{i}\right)$ and that more productive banks enjoy lower costs:

$$
c_{i j, \bullet}=c_{i j, \bullet}\left(\omega_{i}\right) \text { with } \frac{\partial c_{j i, \bullet}}{\partial \omega_{i}}<0
$$

Each bank thus is characterized by a specific productivity level, which also transfers to its foreign affiliates. The costs of supplying financial services internationally are higher than those in the domestic context, such that $c_{i j, L}\left(\omega_{i}\right)<c_{i j, L}^{*}\left(\omega_{i}\right)$, due to the institutional and regulatory differences across financial systems and lack of familiarity with the pool of foreign borrowers.

Therefore, the profits of a bank that establishes foreign affiliates (Mode 2) are:

$$
\begin{aligned}
\Pi(2)_{i j}= & {\left[r_{L}-c_{i j, L}\left(\omega_{i}\right)\right] L(2)_{i}+\left[r_{j, L}^{*}-c_{i j, L}^{*}\left(\omega_{i}\right)\right] L(2)_{i j}^{*}+r_{F} R(2)_{i} } \\
& -\left[r_{D}+c_{i j, D}\left(\omega_{i}\right)\right] D(2)_{i}-F(2)_{j}
\end{aligned}
$$

This specification is similar to Equation (2) with two exceptions. First, we assume that the fixed costs of operating under Mode 2 are higher than the fixed costs of Mode 1, $F(1)_{j}<F(2)_{j}$ (see Cerutti et al. 2007). Second, information costs are lower under Mode 2, because the bank is operating in a foreign country. Without loss of generality, we set these costs to zero for Mode 2. Our specification thus involves a trade-off between the fixed and variable costs of foreign activities, similar to that known in trade literature.

Thus far, our model shares several similarities with models of non-financial firms. The main difference between banks and non-financial firms is that the former care about the risk of their activities, so we follow Rochet (2008) and assume that the bank's objective function increases with expected profits and decreases with risk: ${ }^{7}$

$$
U=U\left[E\left(\Pi_{i j}\right), \sigma^{2}\left(\Pi_{i j}\right)\right], \frac{\partial U}{\partial E\left(\Pi_{i j}\right)}>0, \frac{\partial U}{\partial \sigma^{2}\left(\Pi_{i j}\right)}<0 .
$$

With the simplifying assumption that deposits carry no risk, the variance of the portfolio can be given by $\sigma^{2}\left(\Pi_{i j}\right)=L_{i}^{2} \sigma^{2}+L_{i j}^{* 2} \sigma_{j}^{* 2}+2 L_{i} L_{i j}^{*} \operatorname{COV}_{\mathrm{j}}$, where $\sigma^{2}\left(\sigma_{j}^{* 2}\right)$ is the country-specific risk

\footnotetext{
${ }^{7}$ This specification holds under certain assumptions in an incomplete markets setting; see Rochet (2008).
} 
of domestic (foreign) assets, and $C O V_{j}$ is the covariance matrix of domestic and foreign returns.

We use this model to analyze the intensive and extensive margins of banks' foreign activities. ${ }^{8}$ For the extensive margin, the bank chooses to be active in the foreign country if its expected utility is positive, that is, if $U>0$ holds. Using Equations (3)-(5), it is straightforward to show that the probability of investing abroad is higher with (1) lower fixed costs of foreign activity ( $\left.F_{j}\right)$, (2) lower information costs $\left(\tau_{j}\right)$, (3) higher bank productivity $\left(\omega_{i}\right)$, and (4) lower risk of foreign activities $\left(\sigma_{j}^{* 2}\right)$. Moreover, banks prefer Mode 2 over Mode 1 if their productivity exceeds a threshold $(\bar{\omega})$ - such that banks with $\omega_{i}<\bar{\omega}$ choose Mode 1, but banks with $\omega_{i}>\bar{\omega}$ choose Mode 2 and maintain affiliates abroad - and if the savings in the fixed costs associated with entering through Mode 2 are small relative to the higher variable costs under Mode 1.

The volume of international activities, the intensive margin, can be analyzed by differentiating the objective function with respect to the volume of international risky assets $\left(L_{i j}^{*}\right):^{9}$

$$
\frac{\partial U}{\partial L_{i j}^{*}}=\frac{\partial U}{\partial E\left(\Pi_{i j}\right)}\left[\left(1-\tau_{j}\right) r_{j, L}^{*}-c_{i j, L}^{*}\left(\omega_{i}\right)\right]+2 \frac{\partial U}{\partial \sigma^{2}\left(\Pi_{i j}\right)}\left[L_{i j}^{*} \sigma_{j}^{* 2}+L_{i} \mathrm{COV}_{\mathrm{j}}\right]=0
$$

By denoting the degree of the bank's risk aversion,

$$
\lambda_{i}=-\frac{1}{2} \frac{\partial U}{\partial E\left(\Pi_{i j}\right)} \frac{\partial \sigma^{2}\left(\Pi_{i j}\right)}{\partial U}>0
$$

we can rewrite the first-order condition from Equation (6) as

$$
\frac{\partial U}{\partial L_{i j}^{*}}=\frac{\partial U}{\partial E\left(\Pi_{i j}\right.}\left\{\left(1-\tau_{j}\right) r_{j, L}^{*}-c_{i j, L}^{*}\left(\omega_{i}\right)-\frac{1}{\lambda_{i}}\left(L_{i j}^{*} \sigma_{j}^{* 2}+L_{i} \mathrm{COV}_{\mathrm{j}}\right)\right\}=0 .
$$

With Equation (6'), we obtain comparative static results that demonstrate which banks will increase the volume of their international assets when they experience higher gross returns $\left(r_{L}^{*}\right)$, lower information costs $\left(\tau_{j}\right)$, higher productivity and thus lower variable costs

\footnotetext{
${ }^{8}$ We summarize the results of the comparative static analysis in Table 2.

${ }^{9}$ The qualitative results are the same for the different modes; therefore, we drop the indices.
} 
$\left(c_{i j, L}^{*}\left(\omega_{i}\right)\right)$, lower risk $\left(\sigma_{j}^{* 2}\right)$, lower correlations between domestic and foreign returns (lower $\left.\operatorname{COV}_{\mathrm{j}}\right)$, and lower degrees of risk aversion $\left(\lambda_{i}\right)$.

In summary, our model shows that bank heterogeneity, with regard to productivity and risk aversion, influences internationalization patterns. It also shows some differences and similarities between banks and non-financial firms. For both types of firms, foreign entry becomes more likely when the fixed costs of foreign activity are lower, the savings associated with variable costs are higher, and productivity is higher. The volume of activities also increases with productivity and falls with variable costs. However, banks also take the riskreturn trade-off of their foreign activities into account.

\section{Empirical Methodology}

\subsection{Data about Patterns of Internationalization ${ }^{10}$}

We apply the implications of our proposed model to German bank-level datasets, which were kindly provided by the Deutsche Bundesbank. We use a detailed database on banks' international assets, the so-called External Position Report, to gain comprehensive information about the international assets of domestic banks, their foreign branches, and their foreign subsidiaries year-by-year and country-by-country. We study the database for the years 2002-2006; reporting thresholds for international assets were abolished in January 2002. Therefore, we have exact information about the extensive and intensive margin of banks’ foreign operations, and we do not face problems associated with truncation or censoring.

To obtain information about the extensive margin of banks' foreign operations, we manually link branches and subsidiaries located in country $j$ to their domestic parent bank $i$. We obtain information about the intensive margin of banks' foreign operations by aggregating all assets held in country $j$ across the different modes of foreign activity. We use a composite foreign asset and do not distinguish between different types of assets to keep the analysis tractable. Most of the assets we include are interbank assets. We also complement the External Position Report with information from the annual balance sheets and income statements of all banks operating in Germany between 2000 and 2006. Each bank that holds a German banking license must submit these data to the supervisory authorities.

\footnotetext{
${ }^{10}$ We provide the details in the Data Appendix.
} 
Our dataset therefore contains observations for each bank $(i=2,235)$, each country $(j$ $=58)$, and each year $(t=5)$. Our data cover both members of the Organization for Economic Cooperation and Development (OECD) and non-OECD countries and paints a comprehensive picture of German banks’ foreign activities. We distinguish the following modes of operation:

o Purely domestic banks without foreign activities (Mode 0),

o Banks that hold international assets through their domestic headquarters (Mode 1),

o Banks that maintain foreign branches (Mode 2a), and

o Banks that maintain foreign subsidiaries and/or foreign branches (Mode 2b).

Each bank-year observation may appear in only one of these modes. The ranking of the modes follows the presumed fixed costs involved. Subsidiaries are legally independent, hold their own equity, and are subject to host-country control, so they demand the highest costs in terms of capital requirements and regulatory burden. In addition, foreign subsidiaries often enable large-scale retail operations, which again implies the highest fixed costs, in addition to the regulatory start-up costs (Cerutti et al. 2007).

In Table 1 and Figure 1, we highlight four main characteristics of the internationalization patterns of German banks: First, in Columns 1 and 3 of Table 1, we note the structure of the full sample, which allows for all possible combinations among banks, countries, and years. The allocation of total observations across modes of internationalization is highly dispersed, showing many zero values (almost 80\%) in the bilateral matrix. Approximately $20 \%$ of observations fall in the second category of international assets. The number of observations in Modes 2a and 2b (affiliates) is tiny, accounting for less than 1\% of the total. This high degree of dispersion reflects our decision to allow for all possible combinations among banks, countries, and years.

Second, the data clearly are inflated, because we treat each bank in each country as a separate observation. Determining whether a particular bank is active abroad produces quite a different picture (Columns 3 and 4 of Table 1). On average, only 28 of a total of 2,235 banks are purely domestic, 27 maintain foreign branches, and 37 use subsidiaries and/or branches. The largest group by far consists of banks that hold international assets in at least one foreign country $(2,143)$. Therefore, the evidence for banks differs from that for manufacturing firms, of which only a small subset of firms imports or exports.

Third, not even the large banks with international affiliates operate in all countries (see Table 1, Column 5). If banks hold international assets, they do so in 21 countries on average. 
Banks in Mode 2a keep branches in an average of 12 countries; banks in Mode 2b average subsidiaries in 9 countries.

Fourth, considering the volume of international assets, those held through domestic banks (Mode 1) and those held through foreign branches (Mode 2a) take roughly similar importance (Figure 1). The share of international assets held in foreign subsidiaries (Mode 2b) is small; the relative patterns in the data are similar for mean investments. Comparing the mean and median investment of banks in each country in each mode reveals a substantial amount of heterogeneity across banks. In Mode 1 (international assets), for example, the mean investment is $€ 8.6$ million, though the median is only $€ 0.14$ million.

In summary, our data paint a nuanced picture of the internationalization of German banks. On the one hand, the banking system is highly internationalized, and many banks hold international assets in at least one foreign country. On the other hand, only a few banks maintain foreign affiliates, and investment volumes are dominated by just a few large players.

\subsection{Modeling Extensive and Intensive Margins}

Our basic empirical setup is a self-selection model, in the spirit of Heckman (1979). We replace the conventional selection equation with an ordered probit model to mirror the hierarchy of modes of activities. The extensive margin $(E M)$ reflects the discrete decision of banks: whether and through which mode to be present in a foreign market. Our model of bank $i$ 's operation in country $j$ in year $t$ thus takes the following form:

$$
\begin{aligned}
& I M_{i j t}=\alpha X_{i j t}+\sigma_{I M} u_{i j t} \\
& E M_{i j t}=\beta Z_{i j t}+v_{i j t},
\end{aligned}
$$

where $I M_{i j t}$ describes the intensive margin, and $\sigma_{I M}$ is the standard error of the intensive margin's error term. The error terms $u$ and $v$ are assumed to follow a standard bivariate normal distribution with mean zero, unit variances, and correlation $\rho \cdot{ }^{11}$ Errors are independent from the covariates $X$ and $Z$. We can identify the extensive and the intensive margin when $X$ is a subset of $Z$ (Wooldridge 2002), and we use dummies for different bank groups as exclusion restrictions. The covariates capture productivity, other bank-level, and host country-specific variables, which we describe subsequently (Section 4.1). Because we

\footnotetext{
${ }^{11}$ This specification allows us to apply a standard normal distribution in the correction term, drawing on Winkelmann and Boes (2009).
} 
can observe the intensive margin only if $E M_{i j t}>0$, and because the error terms are correlated, the ordinary least square (OLS) estimates of $\alpha$ would suffer from a selection bias.

We model the extensive margin as an ordered probit model, which yields consistent coefficient estimates of $\beta$, as well as threshold values $\mu_{1}, \mu_{2 a}$, and $\mu_{2 b}$, which separate the categories. The probability that a bank self-selects into four ordinal scaled modes is given by:

$$
\begin{aligned}
\operatorname{Pr}\left(E M_{i j t}=0 \mid Z_{i j t}\right) & =\Phi\left(\mu_{1}-\beta Z_{i j t}\right) \\
\operatorname{Pr}\left(E M_{i j t}=1 \mid Z_{i j t}\right) & =\Phi\left(\mu_{2 a}-\beta Z_{i j t}\right)-\Phi\left(\mu_{1}-\beta Z_{i j t}\right) \\
\operatorname{Pr}\left(E M_{i j t}=2 a \mid Z_{i j t}\right) & =\Phi\left(\mu_{2 b}-\beta Z_{i j t}\right)-\Phi\left(\mu_{2 a}-\beta Z_{i j t}\right) \\
\operatorname{Pr}\left(E M_{i j t}=2 b \mid Z_{i j t}\right) & =1-\Phi\left(\mu_{2 b}-\beta Z_{i j t}\right)
\end{aligned} .
$$

This exposition underpins the pecking order of the different modes of foreign activity, because we must have $\mu_{1}<\mu_{2 a}<\mu_{2 b}$ for the probabilities to be positive. Checking whether the threshold parameters $\mu$ both indicate an ascending order and differ significantly from one another provides a good test for the ordering of the different modes. Furthermore, the estimated cut-off values can be interpreted as proxies for the fixed costs of foreign activity that banks must cover.

To estimate the determinants of the intensive margin, we must take the bias induced by the selection of banks into the different modes into account. For this purpose, we take the conditional expectations of the intensive margin:

$$
E\left[I M_{i j t} \mid Z_{i j t}, E M_{i j t}=k\right\rfloor=\alpha X_{i j t}+\sigma_{I M} E\left\lfloor u_{i j t} \mid Z_{i j t}, E M_{i j t}=k\right\rfloor,
$$

where $k=1,2 a, 2 b$. Using the assumption about the correlation of errors across the margins, we can simplify the conditional expectations of the error term in Equation (10) to

$$
E\left\lfloor\rho v_{i j t} \mid E M_{i j t}=k, Z_{i j t}\right\rfloor=\rho E\left[v_{i j t} \mid \mu_{k}-\beta Z_{i j t}<v_{i j t}<\mu_{k+1}-\beta Z_{i j t}\right\rfloor,{ }^{12}
$$

which resembles the Mills ratio in a standard Heckman model. We replace the conventional selection equation by an ordered probit model, so our corresponding correction term $\lambda_{i j t}^{k}$ depends on the specific mode chosen by bank $i$. The intensive margin thus transforms into:

$$
E\left[I M_{i j t} \mid Z_{i j t}, E M_{i j t}=k\right]=\alpha X_{i j t}+\sigma_{I M} \rho \lambda_{i j t}^{k}
$$

\footnotetext{
${ }^{12}$ See Technical Appendix 7.1 for details.
} 
with

$$
\begin{aligned}
& \lambda_{i j t}^{1}=\frac{\phi\left(\mu_{1}-\beta Z_{i j t}\right)-\phi\left(\mu_{2 a}-\beta Z_{i j t}\right)}{\Phi\left(\mu_{2 a}-\beta Z_{i j t}\right)-\Phi\left(\mu_{1}-\beta Z_{i j t}\right)} \quad \text { if } E M_{i j t}=1 \\
& \lambda_{i j t}^{2 a}=\frac{\phi\left(\mu_{2 a}-\beta Z_{i j t}\right)-\phi\left(\mu_{2 b}-\beta Z_{i j t}\right)}{\Phi\left(\mu_{2 b}-\beta Z_{i j t}\right)-\Phi\left(\mu_{2 a}-\beta Z_{i j t}\right)} \quad \text { if } E M_{i j t}=2 a \\
& \lambda_{i j t}^{2 b}=\frac{\phi\left(\mu_{2 b}-\beta Z_{i j t}\right)}{1-\Phi\left(\mu_{2 b}-\beta Z_{i j t}\right)} \quad \text { if } E M_{i j t}=2 b
\end{aligned}
$$

The correction term specified in Equation (10’) performs a function analogous to that of the inverse Mills ratio in a conventional sample selection (Heckman 1979). Neglecting this term would lead to an omitted variable bias, following from the assumption that $u$ and $v$ in Equation (8) are not independent but instead are bivariate normally distributed. Our hierarchical modeling of the extensive margin thus contains information that affects the estimation of the intensive margin.

\subsection{Measuring Bank Productivity}

The availability of an unbiased measure of bank-level productivity $\left(\omega_{i t}\right)$ is key to our empirical model. Several banking studies measure total factor productivity using a dual approach, which implies the estimation of cost or profit functions, then attribute productivity changes to factor accumulation, technological change, or changes in efficiency (Kumbhakar and Lovell 2000). We use a more direct approach based on a production function. As argued by Olley and Pakes (1996) and Levinsohn and Petrin (2003), this method avoids the violation of the (often implicit) independence assumption between productivity and the factor input choices of banks (see Technical Appendix 7.2). The approach is less common in banking literature though (cf. Nakane and Weintraub 2005, for Brazilian banks).

Considering the ongoing debate about bank production, our choice of banks' inputs and outputs is inevitably heuristic. We follow Nakane and Weintraub (2005) and the theoretical contributions by Martín-Oliver and Salas-Fumás (2008), who suggest a model of bank production, rather than the abundant literature pertaining to the specification of multi-product cost and profit models. Our decision is motivated by two main considerations. First, to make our results comparable to literature investigating non-financial multinational firms (e.g., Greenaway et al. 2007), we use a similar measure of productivity. Second, we prefer the parsimonious measure of productivity that focuses on the volume of financial services 
provided. We also include covariates to control for the risk characteristics of banks, captured by the CAMEL concept (i.e., capitalization, asset quality, managerial skill, earnings, and liquidity).

We specify the aggregate lending volume of a bank as its output (Nakane and Weintraub 2005). That is, banks act as intermediaries between savers and investors (Martín-Oliver and Salas-Fumás 2008), so the volume of borrowing and lending represents bank output. Our first input variable is the sum of deposits and other debt liabilities. The second input is bank staff. In addition to human capital, banks must have physical facilities, such as branches and offices, as well as IT and back-office infrastructures, to provide loans. Because these variables cannot be adjusted quickly, we include fixed assets as a state variable.

To obtain unbiased measures of bank productivity, we also must specify intermediate inputs that perform two functions. First, they must be informative regarding productivity, and second, they must influence output through their impacts on factor accumulation, which is a more subtle choice for banks than for non-financial firms. Levinsohn and Petrin (2003) suggest specifying intermediate inputs, such as materials or electricity subtracted from gross value added, that contribute to the production process and depend on productivity. In our banking application, equity capital can fulfill the key requirements of such an intermediate input. That is, equity rarely is used to fund loans (Mester 1997), but it indicates a bank's risktaking to markets and regulators (Berger 1995) and thus determines funding costs and demand. Because determining optimal levels of (costly) equity capital under regulatory constraints is a key task of bankers, it should correlate with bank productivity.

In Table 3a, we summarize descriptive statistics for the variables we use to estimate bank productivity; in Table 3b, we report the parameter estimates for the production functions. These estimates are fairly similar to those reported by Nakane and Weintraub (2005) for Brazilian banks. We reject constant returns to scale $\left(\beta_{1}+\beta_{2}+\beta_{3}=1\right)$. Our productivity estimates instead indicate slightly decreasing returns to scale, in line with indirect evidence from dual approaches used to estimate scale cost economies in German banking. For comparison, we also report results from basic OLS regressions, which highlight the severe bias in parameters when we neglect the simultaneity of production choices and bank productivity. The OLS intercept can be interpreted as a Solow productivity residual. Because the estimate of productivity $\left(\omega_{i}\right)$ is bank-specific, the left-hand panel in Table 3b lacks this entry. We also do not report the parameter estimate of the intermediate input (equity) in the 
Levinsohn-Petrin specification, because equity is an ancillary parameter, required only to obtain unbiased estimates of productivity.

We report bank productivity and bank-level covariates for the different modes of internationalization in Table 4. With regard to the CAMEL variables, the patterns in the data are quite clear: More complex and more costly modes of international operations are associated with a lower degree of capitalization, lower reserve holdings, lower loan-loss provisions, lower cost-to-income ratios, lower return on equity, and lower liquidity. These findings match the hypothesis that indicates more productive banks are more likely to be active internationally and function in more complex modes; they also are consistent with a productivity pecking order. In addition, banks with a lower revealed degree of risk aversion are more active internationally.

\section{Data and Empirical Results}

\subsection{Explanatory Variables}

The internationalization decision of banks should, according to our theoretical model, depend on various bank-level and country-level parameters, which we specify next. ${ }^{13}$

\subsubsection{Bank-level variables}

Our main measure of bank productivity derives from the production function approach described in Section 3.3. We expect a positive impact. To account for other aspects of bank productivity, we include the cost-to-income ratio (we expect a negative sign), a bank's return on equity (expected positive sign), and an indicator variable to indicate the quintile of the size distribution of the bank's assets (from 1 to 5, expected positive sign) (for a similar specification, see Greenaway et al. 2007).

A bank's degree of risk aversion cannot be observed directly, but the CAMEL profile contains four indirect measures of bank risk. Specifically, banks with a low degree of capitalization, low hidden reserves, high non-performing loans, and low loan-loss provisions should have higher levels of risk and, ceteris paribus, a low degree of risk aversion.

Dummy variables also capture heterogeneity across banks in terms of the different banking groups and locations. A $(0,1)$ dummy for banks located in the former East Germany accounts

\footnotetext{
${ }^{13}$ See also the Data Appendix and Table 2 for a summary of the expected signs. All variables except the dummy variables and those expressed in percentages are in logs.
} 
for the lower degree of international integration of this region compared with the German average. In the selection equation, we also include banking group dummies to distinguish large banks, commercial banks, and savings banks from cooperative banks, as the omitted category.

\subsubsection{Country-level variables}

Larger and more developed markets should make those countries more attractive destinations for international banks, so we expect a positive sign for market size and gross domestic product (GDP) per capita. International banking relates closely to the international activities of non-financial firms, so we also include total German FDI as a proxy for real integration and the demand for financial services by German firms abroad, which we anticipate will have a positive impact. We provide the descriptive statistics in Table 5.

In international finance literature, geographical distance between two countries has become the standard proxy for information costs (e.g., Portes and Rey 2005; Aviat and Coeurdacier 2007; Daude and Fratzscher 2008). Providing financial services to more distant markets or setting up distant foreign affiliates should be more costly than doing business in nearby markets, so we expect a negative sign for distance. As an additional proxy of information costs, we specify a composite index for the level of institutional quality (see also Beck et al. 2006) that comprises six dimensions of indices constructed by Kaufman et al. (1999). A higher value indicates better institutional quality; we expect a positive sign.

International trade (or banking) literature using bilateral data often includes additional dummies, such as the presence of a common border or a common language. We do not include such variables, because we use information for only one source: country of international assets. Language or border dummies would be highly collinear with country fixed effects or geographic distance.

For the portfolio effects, we proxy for macroeconomic, country-specific risks using the standard deviation of GDP growth (growth volatility) in each host country $j$, computed over the past five years. ${ }^{14}$ We expect a negative sign. To measure the correlation between domestic and foreign returns, we use the growth correlation of German and foreign GDP growth rates for rolling windows of five-year periods and again expect a negative sign, because higher

\footnotetext{
${ }^{14}$ We compute growth volatility and growth correlations on the basis of residual GDP growth, regressed on a full set of time-fixed effects, to account for general macroeconomic developments that may influence GDP growth.
} 
correlations imply less potential for diversification. A dummy for countries in the Euro area provides a proxy of the (absence of) exchange rate risk.

Fixed costs of foreign activity: Our first proxy for the fixed costs of foreign activities are activity restrictions faced by banks. This is a discrete measure which indicates restrictions on services and products that banks are allowed to offer, and restrictions on non-financial firm ownership and control (Beck et al. 2006). The expected sign is negative because tighter activity restrictions deter foreign activity. A similar reasoning applies to more stringent capital restrictions, which is the sum of initial and overall capital stringency requirements per country.

Finally, for controls, we include the concentration of the host banking market, though we cannot predict the sign direction a priori. On the one hand, higher concentration could stimulate entry if it indicates higher returns; on the other hand, higher concentration could indicate the presence of implicit barriers to entry. We also feature three dummy variables to indicate whether a country is an offshore destination, is a developing country according to the income taxonomy of the Worldbank, or hosts a financial center.

\subsection{Baseline Regression Results}

We present the baseline results in Table 6, using four different specifications of the extensive and the intensive margin: (1) a baseline model only including bank productivity, (2) the baseline model plus individual bank-level covariates, (3) the baseline model plus bank- and country-level covariates (excluding regulations), and (4) the baseline model plus bank- and all country-level covariates (including regulations). The F-tests show that all groups of variables are jointly significant. We lag all variables by one year to mitigate any reverse causality concerns.

We split the country-level covariates into two subgroups, because regulatory variables are not available for all countries. Our preferred specification is the full specification (see Columns 4 and 8), which captures the fixed costs of entry. Adding the country-level variables significantly increases the explanatory power, especially for the extensive margin (Column 2). In the specification that only features productivity, the $R^{2}$ is 0.01 for the extensive margin (intensive margin 0.10), but the value increases as we add bank-level covariates and dummies (0.13 and 0.21$)$ and the country-level variables (0.40 and 0.29 ). 


\subsubsection{Is There a Productivity Pecking Order?}

Our results support a productivity pecking order in international banking. First, all cut-offs for the extensive margin are significantly different from zero, which indicates a hierarchy of internationalization modes. The higher fixed costs of more complex activities abroad appear in the higher cut-off values. Simple $t$-tests show the first-stage cut-offs are significantly different from one another.

Second, the estimated cut-offs increase more in absolute terms when we move from Mode 1 to Mode 2a compared with the move from Mode 2a to Mode 2b. Considering the interval length relative to a particular coefficient, such as that for productivity $\left(\mu_{k+1}-\mu_{k}\right) / \alpha_{\operatorname{Prod}}$, we note that productivity must increase significantly for a bank to achieve the next category. According to our estimates, opening a subsidiary does not require much more productivity, because the bank already maintains a branch in a specific country (transition from Mode 2a to 2b). In contrast, the additionally required productivity is considerable if the bank moves from Mode 1 (international assets held domestically) to Modes 2a or 2b: $\left(\mu_{2 a}-\mu_{1}\right) / \alpha_{\operatorname{Pr} o d}>\left(\mu_{2 b}-\mu_{2 a}\right) / \alpha_{\text {Prod }}$.

Third, the correction term in the outcome equation varies by mode of activity, which implies that it captures the hierarchy of cut-offs. Previous studies fail to take this selection into a particular mode of internationalization into account; they focus instead on internationally active banks only.

Fourth, productivity has a positive and significant impact on both margins. Paired with the significant cut-offs, this finding offers evidence of a productivity pecking order, which is robust against the addition of other bank-level variables related to productivity. For example, size and return on equity have the expected positive effects; our finding that larger and more profitable banks expand abroad generally is in line with prior literature pertaining to international banking (Focarelli and Pozzolo 2005; Buch and Lipponer 2007). We also demonstrate the joint impact of productivity on both extensive and intensive margins. The cost-to-income ratio has a positive effect on the extensive and a negative effect on the intensive margin. Whereas the latter negative effect is in line with our expectations, the positive impact for the extensive margin may reflect competitive pressures in the bank's home market, which would increase its probability of investing abroad. 


\subsubsection{Impact of Risk Aversion}

The productivity pecking order suggests some similarities between banks and non-financial firms. But an important difference remains: Banks take the risk of their foreign activities explicitly into account. Our results confirm that the degree of risk aversion - which we measure on the basis of high capitalization, high reserves, high loan-loss provisions, and low non-performing loans - is important. With this interpretation, we find that banks that are willing to take on higher risks are more likely to be active internationally; the signs for capitalization and reserves are negative and significant for the extensive margin. Signs for loan-loss provisions and non-performing loans may be consistent with this interpretation, but these variables are not significant in our (preferred) full specification.

The picture changes for the intensive margin, for which the positive signs for capitalization and loan-loss provisions and the negative sign for non-performing loans suggest less riskaverse (more stable) banks do more business. This result may suggest a demand-side effect. Our dependent variable is a composite asset dominated by interbank activities, and in interbank markets, trust in the stability of market participants represents an important determinant of lending relationships. ${ }^{15}$

Overall, our results indicate that the decision to venture abroad is positively affected by a low degree of risk aversion. Once abroad, less risky banks generate higher business volumes.

\subsubsection{Additional Bank-Level Variables}

The dummy variables for the banking groups are significant. Large, commercial banks are more likely to extend abroad than are cooperative banks (omitted category); savings banks are less likely to do so. Banks headquartered in the former East Germany are significantly less active in international markets. Given that the East German banks have invested abroad though, their volume of activity is above average. ${ }^{16}$

\subsubsection{Market Size}

We consistently find a positive impact of market size on the extensive margin, in that GDP, GDP per capita, and total German FDI are positive and significant. The impacts of GDP per capita and German FDI are positive and significant on the intensive margin as well. The

\footnotetext{
${ }^{15}$ The negative sign on hidden reserves is not inconsistent; hidden reserves partly reflect peculiar features of the German accounting system, which may be difficult to verify for foreign partners.

${ }^{16}$ A possible explanation could be the follow-your customer motive. Since only a few East German banks are active internationally, the demand for banking services from home country clients is concentrated on these banks.
} 
volume of foreign assets correlates negatively with market size (GDP), because we control for the volume of FDI. If we drop FDI, we achieve a positive and significant coefficient. In this sense, our results confirm studies that indicate a link between trade and financial integration (e.g., Aviat and Coeurdacier 2007; Kalemli-Ozcan et al. 2009).

\subsubsection{Information Costs}

Our main measure of information costs, geographic distance, reveals the expected negative sign for the extensive margin. When distance increases by 1\%, GDP increases by approximately $1.7 \%\left(-\hat{\beta}_{D i s t} / \hat{\beta}_{G D P}\right)$ for a bank that chooses the same mode of entry. The positive coefficient of distance for the intensive margin again appears due to our inclusion of FDI as our measure for real integration; if we exclude FDI, distance has a negative impact on the intensive margin, too.

The index of institutional quality is insignificant for the extensive and negative for the intensive margin; we expected a positive sign. We only find this positive sign for cooperative banks. For these banks with limited international experience, a good information environment is more important than it is for the larger banks (see Table 8).

\subsubsection{Macroeconomic Portfolio Effects}

To measure portfolio and risk effects at the country level, we use the volatility of foreign GDP growth and the cross-country correlation of GDP growth with Germany (Portes and Rey 2005). Generally, our results support previous studies that use similar data and empirical approaches, in the sense that we find positive impacts of volatility and correlation and thus a “correlation puzzle” (e.g., Portes and Rey 2005 in equity markets; Aviat and Coeurdacier 2007 for banking). Both volatility and correlations should have a negative impact on both margins, but we find this effect only for the impact of volatility on the extensive margin.

Lower exchange rate risk increases German banks’ exposure to Euro area countries. The impact on the extensive margin is positive if we do not control for country-level covariates, but it is negative in our full specification. German banks have a below-average presence in Euro area countries, presumably because those nearby countries can be served from the home market. The positive impact of the Euro on cross-border banking (e.g., Kalemli-Ozcan et al. 2009) might cloud different adjustments along the extensive and intensive margins. 


\subsubsection{Fixed Costs of Foreign Activity}

Tighter activity restrictions and capital regulations have the expected negative impacts on the extensive margin, in support of our use of these variables as proxies for fixed costs. The impact of regulatory restrictions on the volume of activities is positive though; that is, banks that have entered a particular foreign market engage in more activities there. As we show in Table 8 , this positive effect is driven by the large banks, whereas for other banking groups, activity and capital restrictions have a negative impact on the volume of activities. Moreover, for these latter banks, the effect of activity restrictions is greater.

\subsubsection{Country-Level Control Variables}

The concentration results confirm our ambiguous theoretical expectations. Higher concentration in foreign banking markets increases the probability of foreign activity by German banks but lowers the volume. In our baseline specification, we find a negative sign for the offshore dummy, and splitting the sample according to banking group shows that this effect is driven by cooperative banks (see Table 8). For the large banks, the offshore dummy reveals the expected positive sign. The signs for developing countries (negative) and financial centers (positive) match our expectations.

Finally, to put coefficient estimates into perspective, we provide marginal effects in Table 7 for the extensive and intensive margins. Because we use an ordered response model with discrete outcomes to model the extensive margin, the marginal effects differ across modes and indicate the extent of change in the probability of choosing one distinct mode in reaction to a change in a particular explanatory variable (at the mean). As we show in Table 7, macroeconomic variables such as GDP and distance have key impacts on bank internationalization, and they are more important than many of the bank-level variables. In this sense, our results confirm previous literature for non-financial firms. The marginal effects for Mode 2a are insignificant because Modes 2a and $2 \mathrm{~b}$ are very similar.

In summary, we find evidence of a productivity pecking order in international banking and an impact of bank-level risk on internationalization. Banks with less risk aversion appear more internationally oriented, though their volume of activity is lower, ceteris paribus. In addition, banks' foreign activities increase with market size, low information costs, and low entry barriers. The impact of macroeconomic volatility is not clear cut, which is consistent with the "correlation puzzle” (Aviat and Coeurdacier 2007) in previous literature. 


\subsection{Robustness Tests}

We perform several robustness tests based on the panel dimensions of our data and estimates of the model for different banking groups. These unreported results are available on request. The results consistently confirm the pecking order: The estimated cut-offs are significant and increase for more complex modes of foreign activity, the interval length relative to the productivity coefficient declines for more complex modes of activities, and productivity and size have positive and significant impacts.

We initially ignored the panel dimension of our dataset and pooled all observations across years, including time-fixed effects. Estimating the same model by year-by-year gives stable results for most variables, though particularly for those that we use to test the pecking order hypothesis. We also cluster the standard errors at the bank level, at the country level, and at the bank-country level. We bootstrapped the standard errors to consider productivity as a generated regressor. The findings are robust to these variations.

We also use a bank-country fixed effects panel for the intensive margin. The bank-specific productivity measure becomes insignificant, because there is relatively little within-sample variation in bank productivity, which is picked up by the fixed effects. The results for the size measure and the correction term do not change (both are positive and significant).

We also conduct the test suggested by Semykina and Wooldridge (2005) to account for endogenous regressors in the primary equation (our intensive margin equation), as well as heterogeneously distributed and serially dependent error terms in the selection and primary equation. We adapt their method and estimate the extensive margin year-by-year while adding time averages of the bank-level variables. We compute the correction terms separately for each year and include them in the intensive margin equation. The productivity, core banklevel, and macro-level covariates preserve their significance and are qualitatively identical to those reported previously.

An objection to our analysis might note that we pool banks with different internationalization traditions. Therefore, we split the sample into the different banking groups: large, commercial, savings, and cooperative banks. The results in Table 8 reveal similar findings for the country-level covariates; we already have alluded to the differences across banking groups.

Our focus on productivity and risk may ignore that smaller (savings and cooperative) banks might not be as active internationally, despite being highly productive, whether because 
they are legally prevented from operating abroad or because they have access to international markets through their head institutions (e.g., the Landesbanken for savings banks). Our results confirm this expectation only partly. That is, we find a similar pecking order for small and large banks in qualitative terms, but an increase in productivity has a much greater impact on both extensive and intensive margins for smaller than for larger banks. The only banking group for which productivity has a negative impact are commercial banks, which include private banks that often focus on specific segments of the German domestic banking market.

With regard to the risk results, we recognize that smaller banks might be different because, as an example, savings banks fall under public ownership and thus are covered by implicit or explicit state guarantees. However, our results do not confirm that the degree of risk aversion of publicly owned and privately owned banks exert systematically different impacts on internationalization patterns. If anything, more risk-averse, large banks appear more likely to enter foreign markets, though they engage in lower volumes of activities. For the remaining banking groups, risk features matter, but there is no clear link between the degree of risk aversion and the pattern of activities.

Finally, pooling across countries at different stages of development might affect our results. Therefore, we re-estimate the model for OECD countries only; the main results are similar, particularly with regard to the bank-level variables and productivity effects. The impact of country-level variables, such as market size and regulations, may differ slightly.

\section{Conclusions}

Size, productivity, and internationalization decisions by firms obviously relate. Yet despite a vibrant literature focused on explaining the “productivity pecking order” for non-financial firms, we know relatively little about such effects for services firms, such as banks. Bridging this gap and testing whether banks differ represent the main purposes of this research.

From a theoretical point of view, we expect determinants of banks' international activities to be similar to those for non-financial firms. Higher fixed costs deter foreign activity, and banks face a trade-off between fixed and variable costs across different modes of entry. More productive banks should be more likely to invest abroad and hold higher international assets. In addition, bank-specific preferences for risk should affect internationalization decisions.

To analyze the link among productivity, risk, and internationalization patterns empirically, we use a novel, bank-level dataset that includes detailed information about the extensive and 
intensive margins of foreign activity. Our data enable us to distinguish purely domestic banks, banks that hold international assets, banks with foreign branches, and banks with foreign subsidiaries and branches.

We model the internationalization decision of banks in a two-step empirical model. In the first step, we estimate bank-level productivity by applying Levinsohn and Petrin's (2003) model to the banking industry. In the second step, we model the extensive and intensive margins of foreign activity in the spirit of Heckman, using an ordered probit model for the selection equation. Our correction for selection explicitly accounts for the selection into different modes.

Our results then reveal some similarities and differences between the internationalization patterns of banks and non-financial firms. Only the largest banks engage in complex modes of internationalization and set up foreign affiliates, and also similar to the non-financial sector, only a few and large firms engage in FDI. Our findings thus provide robust support for the pecking order hypothesis. More complex and more costly modes of internationalization require greater productivity, so more productive banks tend to engage more internationally than do less productive banks, as well as hold higher international assets. Selection into foreign status therefore has a significant impact on the volume of activities. For banks (as for non-banks), gravity variables are critically important. Larger distances discourage international banking, larger and more developed markets promote international banking, and activity restrictions deter banks.

Yet we also highlight two noteworthy differences between international banking and nonfinancial firms. First, risk factors at the bank level affect their foreign activities. More riskaverse banks are less likely to expand abroad, but they engage in larger volumes of activities. Risk factors at the country level also matter, but the signs of these effects do not always reflect theoretical expectations, which mirrors the correlation puzzle found in previous literature. Second, small, non-financial firms typically are domestically oriented and do not trade or engage in FDI, but smaller banks typically hold foreign assets in at least one market. This finding suggests the smaller fixed costs of holding international assets compared with selling or sourcing abroad. It also indicates that the motive for internationalization differs, and portfolio considerations play an important role for banks.

Our study provides a first step in the exploration of the extensive and intensive margins of foreign banking, and our results have implications for various research streams. In international finance and macroeconomics literature, it would be interesting to explore the 
extent to which adjustments according to the different margins may affect banks' responses to macroeconomic shocks and thus the persistence of shocks. Banking literature could extend our study by exploring how the endogenous sorting of banks into different modes of internationalization, as driven by bank productivity, affects the size distribution and productivity of the banking industry as a whole. Such an investigation ultimately would have implications for the ongoing discussion about the optimal regulation of banks, especially large banks. We leave these issues for further research. 


\section{References}

Aviat, A., and Coeurdacier, N. (2007). The geography of trade in goods and asset holdings. Journal of International Economics 71: 22-51.

Beck, T., Demirguc-Kunt, A., and Levine, R. (2006). Bank concentration, competition, and crises: First results. Journal of Banking and Finance 30: 1581-1603.

Berger, A.N. (1995). The relationship between capital and earnings in banking. Journal of Money Credit and Banking 27: 432-456.

Berger, A.N., Dai, Q., Ongena, S., and Smith, D.C. (2003). To what extent will the banking industry be globalized? A study of bank nationality and reach in 20 European nations. Journal of Banking and Finance 27: 383-415.

Bernard, A.B., Bradford, J.J., Redding, S., and Schott, P. (2007). Firms in international trade. Journal of Economic Perspectives 21: 105-130.

Bernard, A.B., Bradford, J.J., and Schott, P. (2006). Trade costs, firms and productivity. Journal of Monetary Economics 53: 917-937.

Bonfiglioli, A. (2008). Financial integration, productivity and capital accumulation. Journal of International Economics 76: 337-355.

Buch, C.M., and Lipponer, A. (2007). FDI versus exports: Evidence from German banks. Journal of Banking and Finance 31: 805-826.

Cerutti, E., Dell'Ariccia, G., and Martínez Pería, M.S. (2007). How banks go abroad: Branches or subsidiaries? Journal of Banking and Finance 31: 1669-1692.

Cetorelli, N., and Goldberg, L.S. (2008). Banking globalization, monetary transmission, and the lending channel. National Bureau of Economic Research. NBER Working Paper 14101. Cambridge, MA.

Daude, C., and Fratzscher, M. (2008). The pecking order of cross-border investment. Journal of International Economics 74: 94-119.

Focarelli, D., and Pozzolo, A. (2005). Where do banks expand abroad? An empirical analysis. Journal of Business 78: 2435-2465.

Freixas, X., and Rochet, J.C. (1998). Microeconomics of Banking. Cambridge: MIT Press.

Goldberg, L.S. (2004). Financial-sector FDI and host countries: New and old lessons. NBER Working Paper No. 10441. Cambridge, MA.

Greenaway, D., Guariglia, A., and Kneller, R. (2007). Financial factors and exporting decisions. Journal of International Economics 73: 377-395.

Heckman, J. (1979). Sample selection bias as a specification error. Econometrica 47: 153161. 
Helpman, E., Melitz, M.J., and Rubinstein, Y. (2008). Estimating trade flows: Trading partners and trading volumes. Quarterly Journal of Economics 123: 441-487.

Helpman, E., Melitz, M., and Yeaple, S. (2004). Exports versus FDI with heterogeneous firms. American Economic Review 94: 300-316.

Kalemli-Ozcan, S., Papaioannou, E. and Peydro. J.L. (2009). What lies beneath the Euro's effect of financial integration? Currency risk, legal harmonization, or trade? National Bureau of Economic Research (NBER). Working Paper 15034. Cambridge MA.

Kaufman, D., Kraay, A., and Zoido-Lobaton, P. (1999). Governance matters. World Bank Policy Research Department, Working Paper no. 2196.

Kumbhakar, S., and Lovell, K. (2000). Stochastic Frontier Analysis. Cambridge: Cambridge University Press.

Levinsohn, J., and Petrin, A. (2003). Estimating production functions using inputs to control for unobservables. Review of Economic Studies 70: 317-341.

Martín-Oliver, A., and Salas-Fumás, V. (2008). The output and profit contribution of information technology and advertising investments in banks. Journal of Financial Intermediation 17: 229-255.

Melitz, M.J. (2003). The impact of trade on intra-industry reallocations and aggregate industry productivity. Econometrica 71: 1695-1725.

Mester, L.J. (1997). Measuring efficiency at U.S. banks: Accounting for heterogeneity matters. Journal of Operational Research 98: 230-242.

Nakane, M.I., and Weintraub, D.B. (2005). Bank privatization and productivity: Evidence for Brazil. Journal of Banking \& Finance 29: 2259-2289.

Olley, G. S., and Pakes, A. (1996). The dynamics of productivity in the telecommunications equipment industry. Econometrica 64: 1263-1297.

Portes, R., and Rey, H. (2005). The determinants of cross-border equity flows. Journal of International Economics 65: 269-296.

Petrin, A., Poi, B.P., and Levinsohn, J. (2004). Production function estimation in Stata using inputs to control for observables. Stata Journal 4: 113-123.

Rochet, J.-C. (2008). Why are there so many banking crises? In The Politics and Policy of Bank Regulation. Princeton, NJ: Princeton University Press.

Ruckman, K. (2004). Mode of entry mode into a foreign market: The case of U.S. mutual funds in Canada. Journal of International Economics 62: 417-432.

Semykina A., and Wooldridge, J. (2005). Estimating panel data models in the presence of endogeneity and selection: Theory and application. Working Paper. Michigan State University.

Tomiura, E. (2007). Foreign outsourcing, exporting, and FDI: a productivity comparison at the firm level. Journal of International Economics 72: 113-127.

Winkelmann, R., and Boes, S. (2009). Analysis of Microdata, 2d ed. Berlin: Springer. 
Wooldridge, J.M. (2002). Econometric Analysis of Cross Section and Panel Data. Cambridge: MIT Press.

Yeaple, R.S. (2009). Firm heterogeneity and the structure of U.S. multinational activity. Journal of International Economics, forthcoming. 


\section{Technical Appendix}

\subsection{Deriving the Correction Term}

Deriving the correction term, as depicted in Equation (10'), requires us to draw on the standard bivariate normality of error terms in equations that describe the extensive and intensive margins. The starting point is Equation (10), which we repeat here for convenience:

(A.1) $E\left[I M_{i j t} \mid Z_{i j t}, E M_{i j t}=k\right]=\alpha X_{i j t}+\underbrace{\sigma_{I M} E\left[u_{i j t} \mid Z_{i j t}, E M_{i j t}=k\right]}$ where $k=1,2 a, 2 b$

We next focus on the conditional expectations of the error term $\sigma_{I M} E\left[u_{i j t} \mid Z_{i j t}, E M_{i j t}=k\right]$, that is, the last part of Equation (10). Assuming that the errors of the extensive and intensive margin are correlated, we can restate this term as $\sigma_{I M} E\left[\rho v_{i j t} \mid Z_{i j t}, E M_{i j t}=k\right]$. We can further simplify the conditioning part to obtain $\sigma_{I M} \rho E\left[v_{i j t} \mid \mu_{k}-\beta Z_{i j t}<v_{i j t}<\mu_{k+1}-\beta Z_{i j t}\right]$.

If we assume the error term $v_{i j t}$ follows a conditional standard normal distribution, we can explicitly write the conditional expectation as:

$$
\begin{aligned}
& E\left[v_{i j t} \mid \mu_{k}-\beta Z_{i j t}<v_{i j t}<\mu_{k+1}-\beta Z_{i j t}\right]= \\
& \int_{\mu_{k}-\beta Z_{i j t}}^{\mu_{k+1}-\beta Z_{i j t}} v_{i j t} f\left(v_{i j t} \mid \mu_{k}-\beta Z_{i j t}<v_{i j t}<\mu_{k+1}-\beta Z_{i j t}\right) d v_{i j t}
\end{aligned}
$$

Next, rewriting the conditional expectation while applying the definition of a conditional density function yields a ratio of the density $\phi\left(v_{i j t}\right)$ and the cumulative distribution function, such that we can rewrite Equation (A.2) as:

$$
=\frac{1}{\Phi\left(\mu_{k+1}-\beta Z_{i j t}\right)-\Phi\left(\mu_{k}-\beta Z_{i j t}\right)} \int_{\mu_{k}-\beta Z_{i j t}}^{\mu_{k+1}-\beta Z_{i j t}} v_{i j t} \phi\left(v_{i j t}\right) d v_{i j t}
$$

Now, it is possible to integrate and exploit the fact that $\phi^{\prime}\left(v_{i j t}\right)=-v_{i j t} \phi\left(v_{i j t}\right)$ :

$$
=\frac{-\phi\left(\mu_{k+1}-\beta Z_{i j t}\right)-\left(-\phi\left(\mu_{k}-\beta Z_{i j t}\right)\right)}{\Phi\left(\mu_{k+1}-\beta Z_{i j t}\right)-\Phi\left(\mu_{k}-\beta Z_{i j t}\right)}=\frac{\phi\left(\mu_{k}-\beta Z_{i j t}\right)-\phi\left(\mu_{k+1}-\beta Z_{i j t}\right)}{\Phi\left(\mu_{k+1}-\beta Z_{i j t}\right)-\Phi\left(\mu_{k}-\beta Z_{i j t}\right)} .
$$

In turn, we obtain three distinct correction terms $\left(\lambda_{O P}^{k}\right)$ to address the selection bias. Their particular shape and conditionality on the realized modes (categories $0,1,2 \mathrm{a}$, or $2 \mathrm{~b}$ ) of the 
extensive margin level distinguish our ordered probit model from Heckman’s (1979) conventional selection equation. The conditional error term of the intensive margin $\sigma_{I M} E\left[\rho v_{i j t} \mid Z_{i j t}, E M_{i j t}=k\right]$ transforms into:

$\sigma_{I M} \rho \lambda_{i j t}^{1}=\sigma_{I M} \rho \frac{\phi\left(\mu_{1}-\beta Z_{i j t}\right)-\phi\left(\mu_{2 a}-\beta Z_{i j t}\right)}{\Phi\left(\mu_{2 a}-\beta Z_{i j t}\right)-\Phi\left(\mu_{1}-\beta Z_{i j t}\right)} \quad$ if $E M_{i j t}=1 \quad$ for international lending $\sigma_{I M} \rho \lambda_{i j t}^{2 a}=\sigma_{I M} \rho \frac{\phi\left(\mu_{2 a}-\beta Z_{i j t}\right)-\phi\left(\mu_{2 b}-\beta Z_{i j t}\right)}{\Phi\left(\mu_{2 b}-\beta Z_{i j t}\right)-\Phi\left(\mu_{2 a}-\beta Z_{i j t}\right)} \quad$ if $E M_{i j t}=2 a \quad$ for branches $\sigma_{I M} \rho \lambda_{i j t}^{2 b}=\sigma_{I M} \rho \frac{\phi\left(\mu_{2 b}-\beta Z_{i j t}\right)}{1-\Phi\left(\mu_{2 b}-\beta Z_{i j t}\right)} \quad$ if $E M_{i j t}=2 b \quad$ for subsidiaries and branches

which results in the correction term. In the equation for the intensive margin, $\sigma_{E M} \rho$ becomes part of the coefficient to estimate, whereas the regressor $\lambda_{i j t}^{k}$ carries information on the different cut-offs that characterize the extensive margin.

\subsection{Estimating Bank Productivity}

Our estimates of bank productivity rely on the production function approach, in the spirit of Levinsohn and Petrin (2003). Unlike the estimator proposed by Olley and Pakes (1996), this approach can be applied to an unbalanced panel and does not require information about the entry and exit of banks. To illustrate the problem, consider a log-linear Cobb-Douglas production function for bank $i$ in year $t$ :

$$
\ln Y_{i t}=\beta_{0}+\beta_{X} \ln X_{i t}+\beta_{K} \ln K_{i t}+\beta_{Z} \ln Z_{i t}+\omega_{i t}+\eta_{i t} .
$$

In this general exposition, we denote bank output as $Y$, variable input factors by $X$, production factors that are fixed in the short-run by $K$, and intermediate inputs required in the production process as $Z$. Of the two error components, $\omega_{i t}$ denotes unobservable productivity, and $\eta_{i t}$ is a random error term. Only the latter is uncorrelated with banks' input choices. Although widely discussed in empirical literature on production functions, this issue has been virtually neglected in bank productivity studies (cf. Nakane and Weintraub 2005). Banks that experience a positive productivity shock expand their production, which increases their input demand. A negative productivity shock instead reduces their input demand. Interdependency in factor choices and (unobservable) productivity creates biased estimates of $\omega_{i t}$ (Levinsohn and Petrin 2003), which indicates productivity is a state variable that influences a bank's input 
decision, leading to simultaneity problems when estimating production functions. The same problem arises for their dual functions, that is, the cost and profit optimization problems.

Using Levinsohn and Petrin's (2003) estimation approach, we obtain unbiased estimates of the production functions and productivity parameters by exploiting the relationship between banks' demand for intermediate inputs $Z$ and their productivity $\omega_{i t}$. We acknowledge that $Z$ depends on both state variables: temporarily fixed factors $K$ and unobservable productivity $\omega$. Assuming that the demand for $Z$ increases monotonously in productivity, Levinsohn and Petrin (2003) invert the demand function for the intermediate good to obtain:

$$
\omega_{i t}=\omega_{i t}\left(K_{i t}, Z_{i t}\right)
$$

Productivity thus depends on two observable inputs, such that production can be rewritten:

$$
\ln Y_{i t}=\beta_{X} \ln X_{i t}+\phi_{i t}\left(\ln K_{i t}, \ln Z_{i t}\right)+\eta_{i t},
$$

where $\phi_{i t}=\beta_{0}+\beta_{K} \ln K_{i t}+\omega_{i t}\left(\ln K_{i t}, \ln Z_{i t}\right)$. With certain limitations, Equation (A.5) can be estimated by OLS to obtain consistent estimates for the variable input parameters (Olley and Pakes 1996). ${ }^{17}$ However, we cannot separate the impact of state variables on intermediate inputs from their impact on output and therefore require a second step to estimate the coefficient of the state variable $K$ and the parameters determining productivity $\left(\omega_{i t}\right)$. To identify $\beta_{K}$, Levinsohn and Petrin (2003) assume that productivity follows a first-order Markov process:

$$
\omega_{i t}=E\left[\omega_{i t} \mid \omega_{i t-1}\right]+\xi_{i t} .
$$

The term $\xi$ represents productivity innovations, assumed to be independent of $K$. In line with Martín-Oliver and Salas-Fumás (2008), we assume that a bank’s state variable $K$ comprises fixed capital, primarily branch networks, and other tangible assets, such as IT and back-office equipment. In contrast, $\xi$ may correlate with variable factors of bank production, including funds borrowed from depositors and other debt obligations, as well as full-time employees. This potential (contemporaneous) correlation of productivity innovations $\xi$ with factor demand gives rise to the simultaneity problem discussed by Nakane and Weintraub (2005), which we must consider when estimating productivity.

\footnotetext{
${ }^{17}$ Although OLS yields consistent estimates only for the variable input parameter, this provision is sufficient in the two-stage procedure outlined in this appendix.
} 
The assumption that historical intermediate input choices are uncorrelated with contemporaneous innovations in productivity permits the estimation of $\beta_{Z}$. As Petrin and colleagues (2004) suggest, the estimation proceeds as follows: We estimate Equation (A.3) using OLS while replacing $\phi($.$) with a third-order polynomial expansion in \ln K$ and $\ln Z$ :

$$
\text { (A.7) } \quad \ln Y_{i t}=\beta_{0}+\beta_{X} \ln X_{i t}+\sum_{n=0}^{3} \sum_{m=0}^{3-n} \beta_{n m} \ln K^{n}{ }_{i t} \ln Z^{m}{ }_{i t}+\eta_{i t} \text {. }
$$

Thus we gain consistent estimates of $\beta_{X}$ and $\phi_{i t}$ (Levinsohn and Petrin 2003). The second stage of the estimation procedure identifies $\beta_{K}$ (see Equation (A.5)) using the estimate of $\phi_{i t}$ obtained from:

$$
\hat{\phi}_{i t}=\ln \hat{Y}_{i t}-\hat{\beta}_{X} \ln X_{i t}=\hat{\beta}_{0}+\sum_{n=0}^{3} \sum_{m=0}^{3-n} \hat{\beta}_{n m} \ln K^{n}{ }_{i t} \ln Z^{m}{ }_{i t}-\hat{\beta}_{X} X_{i t} .
$$

For given starting values of $\beta_{K} *$, such as those obtained from basic OLS, we can estimate productivity as $\hat{\omega}_{i t}=\hat{\phi}_{i t}-\beta^{*}{ }_{K} \ln K_{i t}$. This estimation yields a consistent, non-parametric approximation of the expectation in Equation (A.6):

$$
\hat{\omega}_{i t}=\gamma_{0}+\gamma_{1} \hat{\omega}_{i t-1}+\gamma_{2} \hat{\omega}_{i t-2}^{2}+\gamma_{3} \hat{\omega}_{i t-3}^{3}+\varepsilon_{i t} .
$$

Finally, we estimate the model with a generalized method of moments approach. We compute the parameters' standard errors using bootstrapping methods, which draw on sampling from the panel of bank $i$ with replacement. 


\section{Data Appendix}

We obtained all bank data from unconsolidated balance sheets, profit and loss accounts, and audit reports reported annually by all banks to the German central bank (Deutsche Bundesbank). The variables for both the productivity estimation and the CAMEL vector are corrected for outliers by truncating at the 1st and 99th percentiles, respectively. Level variables are deflated by the consumer price index. The country-specific variables come from the various sources indicated next.

\section{Bank-Level variables}

Borrowed funds: Sum of deposits and other debt liabilities in million euro.

Capitalization: Core capital as a percentage of gross total assets.

Cost-to-income ratio: Personnel expenditure as a percentage of total administrative cost.

Employees: Full-time equivalents.

Equity: Gross total equity in million euro.

Lending: Total customer loans in million euro.

Loan-loss provisions: Stock of loan-loss provisions as a percentage of gross total loans.

Non-performing loans: Loans with latent risks according to central bank auditors as a percentage of total audited loans.

Physical capital: Fixed assets including IT capital stock in million euro.

Productivity: From Levinsohn and Petrin (2003), estimates of bank productivity.

Reserves: Hidden reserves according to §340f of the German commercial code as a percentage of gross total assets.

Return on equity (ROE): Operating results, including net interest, fees, commissions, and trading income as a percentage of equity capital.

Total assets: Gross total assets.

Definition of banking groups: Large banks represent the head institutions of the savings ('Landesbanken') and cooperative bank sectors, as well as the largest commercial banks. Commercial banks are privately owned but not necessarily publicly listed banks. Savings banks are (local) government-owned regional banks. Cooperative banks are mutually owned regional banks.

\section{Country-level variables}

Activity restrictions: Whether banks are restricted from engaging in securities underwriting, insurance underwriting and selling, real estate investments, management, and development. Higher values indicate more restrictions (Source: Beck et al. 2006).

Concentration: Fraction of total assets held by the three largest banks in the economy (Source: World Bank). 
Capital regulation: Combined measure of overall and initial capital stringency, ranging from 0 to 9, with a higher value indicating greater stringency (Source: Beck at el. 2006).

Developing country: Indicator variable equal to 1 if the country is not a high-income country, according to the income taxonomy of the Worldbank (Source: WDI, Worldbank).

Distance: Geographic distance between Germany and host country $j$ (Source: CEPII, Paris).

Economic freedom: Composite of 10 factors measuring institutional quality and policies pertaining to trade, government finances, government interventions, monetary policy, capital flows and foreign investment, banking and finance, wages and prices, property rights, regulation, and black market activity; higher values indicate better institutions (Source: Beck et al. 2006).

FDI: Aggregate volume of FDI in host country (Source: Microdatabase Foreign Direct Investment (MiDi), Deutsche Bundesbank).

Financial center: Indicator variable equal to 1 for Luxembourg, Switzerland, and the UK, including the channel islands, following the definition of the External Position Report (Source: Deutsche Bundesbank).

GDP per capita: Gross domestic product in million US dollar $(2000=100)$.

GDP-growth correlations: Correlation of German and destination country GDP in the preceding five years.

Institutional quality: Six dimensions of indices: voice and accountability, government effectiveness, political stability, regulatory quality, rule of law, and control of corruption (Kaufman et al. 1999; Beck et al. 2006).

Offshore destination: Indicator variable equal to 1 for Hong Kong, Singapore, and the Philippines, following the definition of the External Position Report (Source: Deutsche Bundesbank).

Volatility: Change of growth rate residuals, net of cyclical effects in the preceding five-year period.

\section{External Position Report}

Data about the international assets of German banks come from the External Position report (Auslandsstatus) of the Deutsche Bundesbank. They are confidential and can be used on the premises of the Deutsche Bundesbank only.

International assets: Loans and advances to banks, companies, governments, bonds and notes, foreign shares and other equity, participation abroad, denominated or converted into euro.

Branches and subsidiaries: Foreign affiliates of German parent banks. Branches do not enjoy independent legal status, whereas subsidiaries do. Assets held by affiliates are attributed to the country in which they are located.

List of countries: United Arab Emirates, Argentina, Austria, Australia, Belgium, Bulgaria, Brazil, Canada, Switzerland, Chile, China, Cyprus, Czech Republic, Denmark, Estonia, Egypt, Spain, Finland, France, Greece, Hong Kong, Hungary, Indonesia, Ireland, Israel, India, Italy, Japan, South Korea, Cayman Islands, Lithuania, Luxemburg, Latvia, Morocco, Malta, Mexico, Malaysia, Netherlands, Norway, New Zealand, Philippines, Poland, Portugal, 
Romania, Russia, Saudi Arabia, Sweden, Singapore, Slovenia, Slovakia, Thailand, Turkey, Taiwan, Ukraine, United Kingdom, United States, Vietnam, South Africa. 
Table 1: Modes of Internationalization

\begin{tabular}{|c|c|c|c|c|c|}
\hline & $\begin{array}{c}\text { (1) } \\
\text { Number of bank- } \\
\text { year-country } \\
\text { observations }\end{array}$ & $\begin{array}{l}(2) \\
\%\end{array}$ & $\begin{array}{l}\text { (3) } \\
\text { Number of } \\
\text { banks }\end{array}$ & $\begin{array}{l}\text { (4) } \\
\%\end{array}$ & $\begin{array}{l}\text { (5) } \\
\text { Average } \\
\text { number of } \\
\text { foreign } \\
\text { countries }\end{array}$ \\
\hline $\begin{array}{l}\text { Mode } 0 \text { (No foreign } \\
\text { activities) }\end{array}$ & 507,947 & 79.70 & 28 & 1.25 & - \\
\hline $\begin{array}{l}\text { Mode } 1 \\
\text { (International assets) }\end{array}$ & 128,262 & 20.13 & 2,143 & 95.88 & 21 \\
\hline $\begin{array}{l}\text { Mode 2a (Foreign } \\
\text { branches) }\end{array}$ & 640 & 0.10 & 27 & 1.21 & 13 \\
\hline $\begin{array}{l}\text { Mode } 2 \mathrm{~b} \text { (Foreign } \\
\text { branches and } \\
\text { subsidiaries) }\end{array}$ & 459 & 0.07 & 37 & 1.66 & 9 \\
\hline
\end{tabular}

Notes: Data are based on the full dataset of 2,235 banks, 58 countries, and 5 years (2002-2006). Columns 1 and 2 reflect the full, expanded dataset using all bank-country-year combinations, Columns 3 and 4 use the dataset collapsed by banks; Column 5 gives the average number of countries in which banks in each mode are active. Mode 0 indicates that there are no activities of bank $i$ in country $j$ in year $t$. 
Table 2: Theoretical Predictions and Measurement

\begin{tabular}{|c|c|c|c|c|}
\hline \multirow[b]{2}{*}{ Parameter } & \multirow[b]{2}{*}{ Measurement } & \multicolumn{3}{|c|}{ Expected Signs } \\
\hline & & $\begin{array}{l}\text { Extensive } \\
\text { margin }\end{array}$ & $\begin{array}{l}\text { Intensive } \\
\text { margin }\end{array}$ & $\begin{array}{c}\text { Mode } 2 \\
\succ \text { Mode 1? }\end{array}$ \\
\hline \multicolumn{5}{|c|}{ Bank level } \\
\hline Bank productivity $\omega_{i}$ & $\begin{array}{l}\text { Productivity, cost-to-income ratio, } \\
\text { return on equity, size }\end{array}$ & + & + & + \\
\hline Bank risk aversion & $\begin{array}{l}\text { High risk aversion: Capitalization, } \\
\text { reserves, loan-loss provisions }\end{array}$ & & & \\
\hline$\lambda_{i}$ & $\frac{\text { Low risk aversion: Non- }}{\text { performing loans }}$ & - & - & - \\
\hline \multicolumn{5}{|c|}{$\underline{\text { Country level }}$} \\
\hline $\begin{array}{l}\text { Fixed costs of foreign } \\
\text { activity } F_{j}(\cdot)\end{array}$ & $\begin{array}{l}\text { Activity restrictions, capital } \\
\text { restrictions }\end{array}$ & - & 0 & - \\
\hline Expected returns $r_{L}^{*}$ & $\begin{array}{l}\text { GDP, GDP per capita, German } \\
\text { FDI }\end{array}$ & + & + & + \\
\hline Information costs $\tau_{j}$ & Distance, institutional quality & - & - & + \\
\hline Country risk $\sigma_{j}^{*}$ & GDP growth volatility & - & - & - \\
\hline Return correlations & $\begin{array}{l}\text { Correlation between domestic and } \\
\text { foreign GDP growth }\end{array}$ & - & - & - \\
\hline
\end{tabular}


Table 3: Bank Productivity Estimates

(a) Descriptive Statistics: Bank Production Variables

\begin{tabular}{|c|c|c|c|c|c|c|}
\hline \multirow[t]{2}{*}{ Variable } & & \multirow[t]{2}{*}{ Mean } & \multirow[t]{2}{*}{ S.d. } & \multicolumn{3}{|c|}{ Percentiles } \\
\hline & & & & $1 s t$ & $50 t h$ & 99th \\
\hline Lending & $Y$ & 1,333.6 & $11,666.6$ & 5.1 & 197.4 & $18,939.7$ \\
\hline Borrowed funds & $X_{1}$ & $1,257.9$ & $10,329.0$ & 5.9 & 233.7 & $13,023.9$ \\
\hline Employees & $X_{2}$ & 270.6 & $1,188.4$ & 5.4 & 92.0 & $2,593.0$ \\
\hline Equity & $Z$ & 106.0 & 722.0 & 1.3 & 19.2 & $1,506.1$ \\
\hline Physical capital & $K$ & 14.9 & 56.1 & 0.1 & 5.1 & 140.6 \\
\hline
\end{tabular}

(b) Production Function Estimates

\begin{tabular}{|c|c|c|c|c|c|c|}
\hline & \multicolumn{3}{|c|}{ Levinsohn-Petrin } & \multicolumn{3}{|c|}{ OLS } \\
\hline & Coefficient & S.d. & p-value & Coefficient & S.d. & p-value \\
\hline ln Employees & 0.176 & 0.049 & 0.000 & 0.577 & 0.010 & 0.000 \\
\hline ln Borrowed funds & 0.404 & 0.067 & 0.000 & 0.526 & 0.007 & 0.000 \\
\hline ln Physical capital & 0.240 & 0.032 & 0.000 & -0.035 & 0.007 & 0.000 \\
\hline \multirow[t]{2}{*}{ Constant } & & & & -0.129 & 0.030 & 0.000 \\
\hline & $\mathrm{Chi}^{2}$ & & p-value & F-test & & p-value \\
\hline Ho: $\beta_{1}+\beta_{2}+\beta_{3}=1$ & 17.4 & & 0.000 & 345.8 & & 0.000 \\
\hline$R^{2}$ & & & & 0.597 & & \\
\hline
\end{tabular}

Notes: In Table 3a, the data are based on 12,569 observations for 2,439 banks between 2000 and 2006. All monetary volumes are in million euro. Employees are full-time equivalents. Borrowed funds are the sum of deposits and other debt liabilities. In Table 3b, estimates are based on 12,569 bank-year observations for the years 2000-2006. Time-specific fixed effects are included but not reported. Bootstrapped standard errors are reported for estimates, following Levinsohn and Petrin (2003); OLS estimates are based on robust standard errors. 
Table 4: CAMEL Profile and Productivity by Internationalization Mode

\begin{tabular}{|c|c|c|c|c|c|c|c|c|c|c|}
\hline & \multicolumn{2}{|c|}{ Domestic } & \multicolumn{2}{|c|}{ International assets } & \multicolumn{2}{|c|}{ Foreign branches } & \multicolumn{2}{|c|}{ Subsidiaries } & \multicolumn{2}{|c|}{ All banks } \\
\hline & Mean & S.d. & Mean & S.d. & Mean & S.d. & Mean & S.d. & Mean & S.d. \\
\hline Capitalization & 5.85 & 3.11 & 5.42 & 2.62 & 4.10 & 3.40 & 3.78 & 4.46 & 5.76 & 3.02 \\
\hline Cost-income ratio & 44.10 & 9.17 & 41.07 & 10.56 & 25.65 & 14.69 & 26.23 & 12.09 & 43.45 & 9.58 \\
\hline Hidden reserves & 1.41 & 1.04 & 1.34 & 1.05 & 0.17 & 0.29 & 0.16 & 0.24 & 1.39 & 1.04 \\
\hline Loan-loss provisions & 5.40 & 7.83 & 5.17 & 10.61 & 2.94 & 4.20 & 2.54 & 2.88 & 5.35 & 8.46 \\
\hline Non-performing loans & 0.96 & 1.21 & 0.97 & 1.03 & 0.81 & 0.86 & 0.66 & 0.61 & 0.96 & 1.18 \\
\hline Productivity & 11.78 & 25.63 & 19.66 & 33.99 & 115.53 & 60.76 & 112.29 & 61.60 & 13.56 & 28.13 \\
\hline Return on Equity & 10.52 & 16.32 & 10.98 & 14.58 & 7.50 & 17.76 & 5.69 & 14.63 & 10.61 & 15.98 \\
\hline
\end{tabular}

Notes: Descriptive statistics of parent bank-specific variables, measured in percentages except for productivity. Parent banks are sorted by their mode of internationalization: Mode 1 (International assets), Mode 2a (Foreign branches), and Mode 2b (Branches and subsidiaries). Variable definitions appear in the Data Appendix.

Table 5: Country-Specific Variables

\begin{tabular}{|c|c|c|c|c|c|c|}
\hline \multirow[b]{2}{*}{ Variable } & \multirow[b]{2}{*}{ Unit } & \multirow[b]{2}{*}{ Mean } & \multirow[b]{2}{*}{ S.d. } & \multicolumn{2}{|c|}{ Percentiles } & \multirow[b]{2}{*}{$\mathrm{N}$} \\
\hline & & & & $1 s t$ & 99th & \\
\hline Activity restrictions & Score & 8.89 & 2.53 & 4.00 & 14.00 & 174 \\
\hline Capital regulation & Score & 5.50 & 1.55 & 2.00 & 8.00 & 174 \\
\hline Concentration of banking market & $\%$ & 64.24 & 20.54 & 22.73 & 99.32 & 304 \\
\hline Developing destination & 0/1 indicator & 0.52 & 0.50 & 0.00 & 1.00 & 304 \\
\hline Distance & Kilometers & 4.92 & 4.55 & 0.28 & 18.12 & 304 \\
\hline Financial center destination & $0 / 1$ indicator & 0.05 & 0.22 & 0.00 & 1.00 & 304 \\
\hline Foreign direct investment (FDI) & Bn EUR & 11.60 & 30.90 & 0.01 & 212.00 & 304 \\
\hline GDP growth correlations & $\%$ & 35.44 & 49.63 & -80.33 & 98.79 & 304 \\
\hline Gross domestic product (GDP) & Bn USD & 597.00 & $1,610.00$ & 5.25 & $10,900.00$ & 304 \\
\hline Institutional quality & Score & 3.53 & 0.52 & 2.18 & 4.50 & 174 \\
\hline Offshore destination & 0/1 indicator & 0.05 & 0.22 & 0.00 & 1.00 & 304 \\
\hline GDP per capita (log) & Tsd USD & 16.54 & 16.71 & 0.57 & 71.87 & 304 \\
\hline Volatility of foreign GDP & $\%$ & 1.91 & 1.58 & 0.36 & 7.74 & 304 \\
\hline
\end{tabular}


Table 6: Baseline Estimation Results for the Extensive and Intensive Margins

\begin{tabular}{|c|c|c|c|c|c|c|c|c|}
\hline & \multicolumn{4}{|c|}{ Extensive Margin } & \multicolumn{4}{|c|}{ Intensive Margin } \\
\hline & Productivity & Micro & Macro & Regulation & Productivity & Micro & Macro & Regulation \\
\hline \multicolumn{9}{|l|}{ Productivity and selection } \\
\hline Correction term & & & & & $\begin{array}{c}3.9406 * * * \\
(0.0548)\end{array}$ & $\begin{array}{c}-0.4161^{* * *} \\
(0.0397)\end{array}$ & $\begin{array}{c}0.2836 * * * \\
(0.0301)\end{array}$ & $\begin{array}{c}0.5669 * * * \\
(0.0372)\end{array}$ \\
\hline Productivity & $\begin{array}{c}0.0048^{* * *} \\
(0.0000)\end{array}$ & $\begin{array}{c}0.0004 * * * \\
(0.0001)\end{array}$ & $\begin{array}{c}0.0006 * * * \\
(0.0001)\end{array}$ & $\begin{array}{c}0.0005 * * * \\
(0.0001)\end{array}$ & $\begin{array}{c}0.0346 * * * \\
(0.0003)\end{array}$ & $\begin{array}{c}0.0128 * * * \\
(0.0003)\end{array}$ & $\begin{array}{c}0.0146 * * * \\
(0.0003)\end{array}$ & $\begin{array}{c}0.0155^{* * *} \\
(0.0003)\end{array}$ \\
\hline Size & & $\begin{array}{c}0.2791 * * * \\
(0.0019)\end{array}$ & $\begin{array}{c}0.4124 * * * \\
(0.0024)\end{array}$ & $\begin{array}{c}0.4356 * * * \\
(0.0030)\end{array}$ & & $\begin{array}{c}0.1862 * * * \\
(0.0107)\end{array}$ & $\begin{array}{c}0.4252 * * * \\
(0.0099)\end{array}$ & $\begin{array}{c}0.5262 * * * \\
(0.0116)\end{array}$ \\
\hline \multicolumn{9}{|l|}{ Bank-specific variables } \\
\hline Cost-income ratio & & $\begin{array}{c}0.0047 * * * \\
(0.0003)\end{array}$ & $\begin{array}{c}0.0069 * * * \\
(0.0003)\end{array}$ & $\begin{array}{c}0.0071 * * * \\
(0.0004)\end{array}$ & & $\begin{array}{c}-0.0598 * * * \\
(0.0011)\end{array}$ & $\begin{array}{c}-0.0591^{* * *} \\
(0.0011)\end{array}$ & $\begin{array}{c}-0.0561^{* * *} \\
(0.0013)\end{array}$ \\
\hline Return on equity & & $\begin{array}{c}0.0015^{* * *} \\
(0.0002)\end{array}$ & $\begin{array}{c}0.0021^{* * * *} \\
(0.0002)\end{array}$ & $\begin{array}{c}0.0016^{* * *} \\
(0.0002)\end{array}$ & & $\begin{array}{c}-0.0003 \\
(0.0007)\end{array}$ & $\begin{array}{c}0.0011^{*} \\
(0.0006)\end{array}$ & $\begin{array}{c}0.0017^{* *} \\
(0.0008)\end{array}$ \\
\hline Capitalization & & $\begin{array}{c}-0.0129 * * * \\
(0.0008)\end{array}$ & $\begin{array}{c}-0.0185 * * * \\
(0.0010)\end{array}$ & $\begin{array}{c}-0.0188 * * * \\
(0.0012)\end{array}$ & & $\begin{array}{c}0.0279 * * * \\
(0.0035)\end{array}$ & $\begin{array}{c}0.0195 * * * \\
(0.0033)\end{array}$ & $\begin{array}{c}0.0212 * * * \\
(0.0038)\end{array}$ \\
\hline Hidden reserves & & $\begin{array}{c}-0.0068^{* * *} \\
(0.0022)\end{array}$ & $\begin{array}{c}-0.0131^{* * *} \\
(0.0026)\end{array}$ & $\begin{array}{c}-0.0095 * * * \\
(0.0032)\end{array}$ & & $\begin{array}{c}-0.1803 * * * \\
(0.0089)\end{array}$ & $\begin{array}{c}-0.2281 * * * \\
(0.0084)\end{array}$ & $\begin{array}{c}-0.2346^{* * *} \\
(0.0098)\end{array}$ \\
\hline Non-performing loans & & $\begin{array}{c}0.0053^{* *} \\
(0.0023)\end{array}$ & $\begin{array}{c}0.0061^{* *} \\
(0.0027)\end{array}$ & $\begin{array}{c}0.0035 \\
(0.0033)\end{array}$ & & $\begin{array}{c}-0.1177 * * * \\
(0.0114)\end{array}$ & $\begin{array}{c}-0.1006 * * * \\
(0.0108)\end{array}$ & $\begin{array}{c}-0.0805^{* * *} \\
(0.0125)\end{array}$ \\
\hline Loan-loss provisions & & $\begin{array}{l}-0.0005^{*} \\
(0.0002)\end{array}$ & $\begin{array}{c}-0.0004 \\
(0.0003)\end{array}$ & $\begin{array}{c}-0.0002 \\
(0.0003)\end{array}$ & & $\begin{array}{c}0.0143^{* * *} \\
(0.0010)\end{array}$ & $\begin{array}{c}0.0147 * * * \\
(0.0009)\end{array}$ & $\begin{array}{c}0.0131 * * * \\
(0.0011)\end{array}$ \\
\hline \multicolumn{9}{|l|}{ Country-specific variables } \\
\hline Gross domestic product (GDP) & & & $\begin{array}{c}0.1833 * * * \\
(0.0028)\end{array}$ & $\begin{array}{c}0.1980 * * * \\
(0.0054)\end{array}$ & & & $\begin{array}{c}-0.4378 * * * \\
(0.0112)\end{array}$ & $\begin{array}{c}-1.0102^{* * *} \\
(0.0212)\end{array}$ \\
\hline GDP per capita & & & $\begin{array}{c}0.3570 * * * \\
(0.0046)\end{array}$ & $\begin{array}{c}0.1343 * * * \\
(0.0094)\end{array}$ & & & $\begin{array}{c}-0.1860 * * * \\
(0.0206)\end{array}$ & $\begin{array}{c}0.6595 * * * \\
(0.0438)\end{array}$ \\
\hline German FDI & & & $\begin{array}{c}0.1996 * * * \\
(0.0026)\end{array}$ & $\begin{array}{c}0.2881 * * * \\
(0.0042)\end{array}$ & & & $\begin{array}{c}0.7133 * * * \\
(0.0114)\end{array}$ & $\begin{array}{c}0.9179 * * * \\
(0.0165)\end{array}$ \\
\hline Growth correlations & & & $\begin{array}{c}0.2469 * * * \\
(0.0066)\end{array}$ & $\begin{array}{c}0.1278^{* * *} \\
(0.0099)\end{array}$ & & & $\begin{array}{l}-0.0526^{*} \\
(0.0290)\end{array}$ & $\begin{array}{l}-0.0247 \\
(0.0388)\end{array}$ \\
\hline Growth volatility & & & $\begin{array}{c}-0.0074 * * * \\
(0.0019)\end{array}$ & $\begin{array}{c}-0.0740 * * * \\
(0.0026)\end{array}$ & & & $\begin{array}{c}0.1523 * * * \\
(0.0084)\end{array}$ & $\begin{array}{c}0.1303^{* * *} \\
(0.0122)\end{array}$ \\
\hline Distance & & & $\begin{array}{c}-0.1757 * * * \\
(0.0029)\end{array}$ & $\begin{array}{c}-0.3426 * * * \\
(0.0043)\end{array}$ & & & $\begin{array}{c}0.1656 * * * \\
(0.0119)\end{array}$ & $\begin{array}{c}0.3885 * * * \\
(0.0172)\end{array}$ \\
\hline Concentration & & & $\begin{array}{c}0.6128 * * * \\
(0.0135)\end{array}$ & $\begin{array}{c}0.1565^{* * *} * \\
(0.0211)\end{array}$ & & & $\begin{array}{c}-1.6782 * * * \\
(0.0502)\end{array}$ & $\begin{array}{c}-3.9171^{* * *} \\
(0.0825)\end{array}$ \\
\hline Activity restrictions & & & & $\begin{array}{c}-0.0876^{* * *} \\
(0.0019)\end{array}$ & & & & $\begin{array}{c}0.0244 * * * \\
(0.0070)\end{array}$ \\
\hline Capital restrictions & & & & $\begin{array}{c}-0.1109 * * * \\
(0.0021)\end{array}$ & & & & $\begin{array}{c}0.0361 * * * \\
(0.0078)\end{array}$ \\
\hline Institutional quality & & & & $\begin{array}{c}0.0096 \\
(0.0142)\end{array}$ & & & & $\begin{array}{c}-0.2245^{* * * *} \\
(0.0565)\end{array}$ \\
\hline \multicolumn{9}{|l|}{ Intercepts and fixed effects } \\
\hline East German banks & & $\begin{array}{c}-0.2115 * * * \\
(0.0072)\end{array}$ & $\begin{array}{c}-0.3270 * * * \\
(0.0087)\end{array}$ & $\begin{array}{c}-0.3510^{* * *} \\
(0.0108)\end{array}$ & & $\begin{array}{c}0.7536 * * * \\
(0.0326)\end{array}$ & $\begin{array}{c}0.6434 * * * \\
(0.0308)\end{array}$ & $\begin{array}{c}0.4145 * * * \\
(0.0357)\end{array}$ \\
\hline Large banks & & $\begin{array}{c}1.6847 * * * \\
(0.0204)\end{array}$ & $\begin{array}{c}2.3272 * * * \\
(0.0232)\end{array}$ & $\begin{array}{c}2.3492 * * * \\
(0.0319)\end{array}$ & & & & \\
\hline Commercial banks & & $\begin{array}{c}0.2607 * * * \\
(0.0084)\end{array}$ & $\begin{array}{c}0.4064^{* * *} \\
(0.0097)\end{array}$ & $\begin{array}{c}0.3578 * * * \\
(0.0125)\end{array}$ & & & & \\
\hline Savings banks & & $\begin{array}{c}-0.1059 * * * \\
(0.0057)\end{array}$ & $\begin{array}{c}-0.1421^{* * *} \\
(0.0068)\end{array}$ & $\begin{array}{c}-0.1628 * * * \\
(0.0086)\end{array}$ & & & & \\
\hline Euro Area & & $\begin{array}{c}0.8850 * * * \\
(0.0047)\end{array}$ & $\begin{array}{c}-0.1416 * * * \\
(0.0063)\end{array}$ & $\begin{array}{c}-0.4961^{* * *} \\
(0.0095)\end{array}$ & & $\begin{array}{c}1.9278^{* * *} \\
(0.0305)\end{array}$ & $\begin{array}{c}1.7396 * * * \\
(0.0214)\end{array}$ & $\begin{array}{c}2.2315^{* * * *} \\
(0.0359)\end{array}$ \\
\hline Offshore destination & & & $\begin{array}{c}-0.3893 * * * \\
(0.0147)\end{array}$ & $\begin{array}{c}-0.1526 * * * \\
(0.0192)\end{array}$ & & & $\begin{array}{c}-0.9356 * * * \\
(0.0684)\end{array}$ & $\begin{array}{c}-0.7185 * * * \\
(0.0912)\end{array}$ \\
\hline Developing destination & & & $\begin{array}{c}-0.3778 * * * \\
(0.0106)\end{array}$ & $\begin{array}{c}-0.3885 * * * \\
(0.0194)\end{array}$ & & & $\begin{array}{c}0.1888 * * * \\
(0.0501)\end{array}$ & $\begin{array}{c}-1.0713^{* * * *} \\
(0.0943)\end{array}$ \\
\hline Financial center destination & & & $\begin{array}{c}0.8502 * * * \\
(0.0106)\end{array}$ & $\begin{array}{c}0.3274 * * * \\
(0.0159)\end{array}$ & & & $\begin{array}{c}0.3207 * * * \\
(0.0290)\end{array}$ & $\begin{array}{c}1.1554 * * * \\
(0.0414)\end{array}$ \\
\hline Constant & & & & & $\begin{array}{c}-1.2847 * * * \\
(0.0788)\end{array}$ & $\begin{array}{c}5.8681 * * * \\
(0.1010)\end{array}$ & $\begin{array}{c}6.6187 * * * \\
(0.3484)\end{array}$ & $\begin{array}{c}10.5808 * * * \\
(0.5585)\end{array}$ \\
\hline Cut-off 1 & $\begin{array}{c}0.8998 * * * \\
(0.0019)\end{array}$ & $\begin{array}{c}2.0056 * * * \\
(0.0172)\end{array}$ & $\begin{array}{c}12.4399 * * * \\
(0.0638)\end{array}$ & $\begin{array}{c}8.7965 * * * \\
(0.1201)\end{array}$ & & & & \\
\hline Cut-off 2 & $\begin{array}{c}3.0711^{* * *} \\
(0.0103)\end{array}$ & $\begin{array}{c}4.6935 * * * \\
(0.0226)\end{array}$ & $\begin{array}{c}16.0496 * * * \\
(0.0683)\end{array}$ & $\begin{array}{c}12.7090 * * * \\
(0.1230)\end{array}$ & & & & \\
\hline Cut-off 3 & $\begin{array}{c}3.3637 * * * \\
(0.0149)\end{array}$ & $\begin{array}{c}5.0845 * * * \\
(0.0267)\end{array}$ & $\begin{array}{c}16.4922 * * * \\
(0.0700)\end{array}$ & $\begin{array}{c}13.2597 * * * \\
(0.1253)\end{array}$ & & & & \\
\hline \multicolumn{9}{|l|}{ Observations and diagnostics } \\
\hline Observations & 632,835 & 618,786 & 608,964 & 343,770 & 128,745 & 126,964 & 126,885 & 94,329 \\
\hline McFadden $R^{2}$ & 0.0133 & 0.1347 & 0.4028 & 0.4125 & 0.1015 & 0.2096 & 0.2922 & 0.2893 \\
\hline F-tests: All equal to zero & & 86,490 & 256,636 & 170,327 & & 2,246 & 2,096 & 1,372 \\
\hline Micro & & 25,434 & 35,476 & 24,818 & & 619.6 & 995.2 & 798.5 \\
\hline Macro & & & 114,927 & 63,585 & & & 1,419 & 938.4 \\
\hline Regulation & & & & 5,299 & & & & 16.27 \\
\hline Banking groups & & 8,648 & 12,732 & 6,942 & & & & \\
\hline
\end{tabular}


Notes: The selection equation (Extensive Margin) is estimated as an ordered probit model and includes unreported dummies for banking groups as exclusion restrictions. The dependent variable is the mode of foreign presence. The primary equation (Intensive Margin) is estimated with OLS. The dependent variable is the log volume of international assets. Standard errors are in brackets, and time-fixed effects are included but not reported. Productivity is obtained by the method proposed by Levinsohn and Petrin (2003). For further variable descriptions, see the Data Appendix. ${ }^{* * *}$ Significant at $1 \%$ level. ${ }^{* *}$ Significant at 5\% level. * Significant at $10 \%$ level. 
Table 7: Marginal Effects

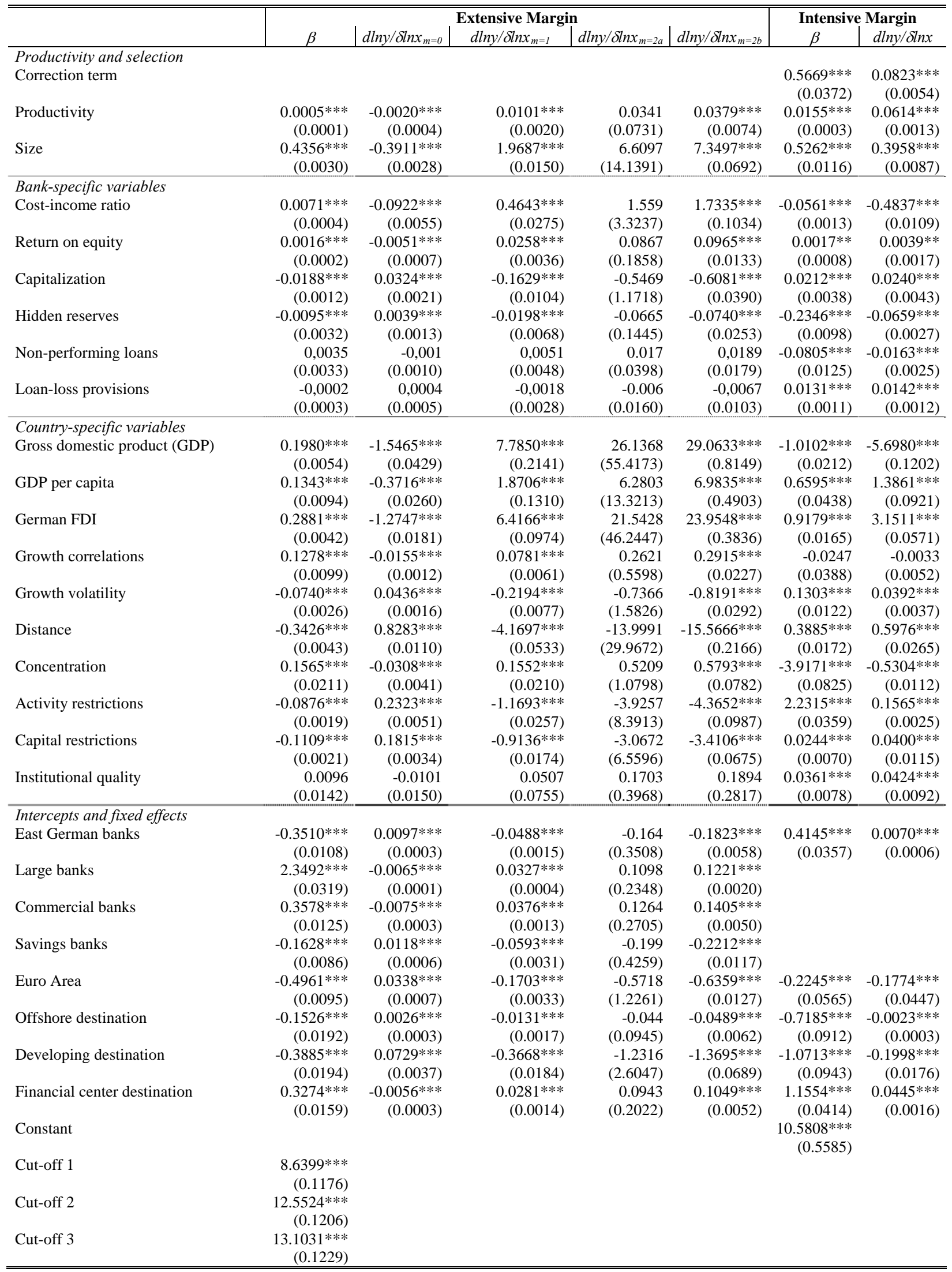


Notes: The selection equation (Extensive Margin) is estimated as an ordered probit model and includes unreported dummies for banking groups as exclusion restrictions. The dependent variable is the mode of foreign presence. The primary equation (Intensive Margin) is estimated with OLS. The dependent variable is the log volume of international assets. Time-fixed effects are included but not reported. Productivity is obtained using the method proposed by Levinsohn and Petrin (2003). For further variable descriptions, see the Data Appendix. ***Significant at $1 \%$ level. **Significant at $5 \%$ level. * Significant at $10 \%$ level. 
Table 8: Results per Banking Group

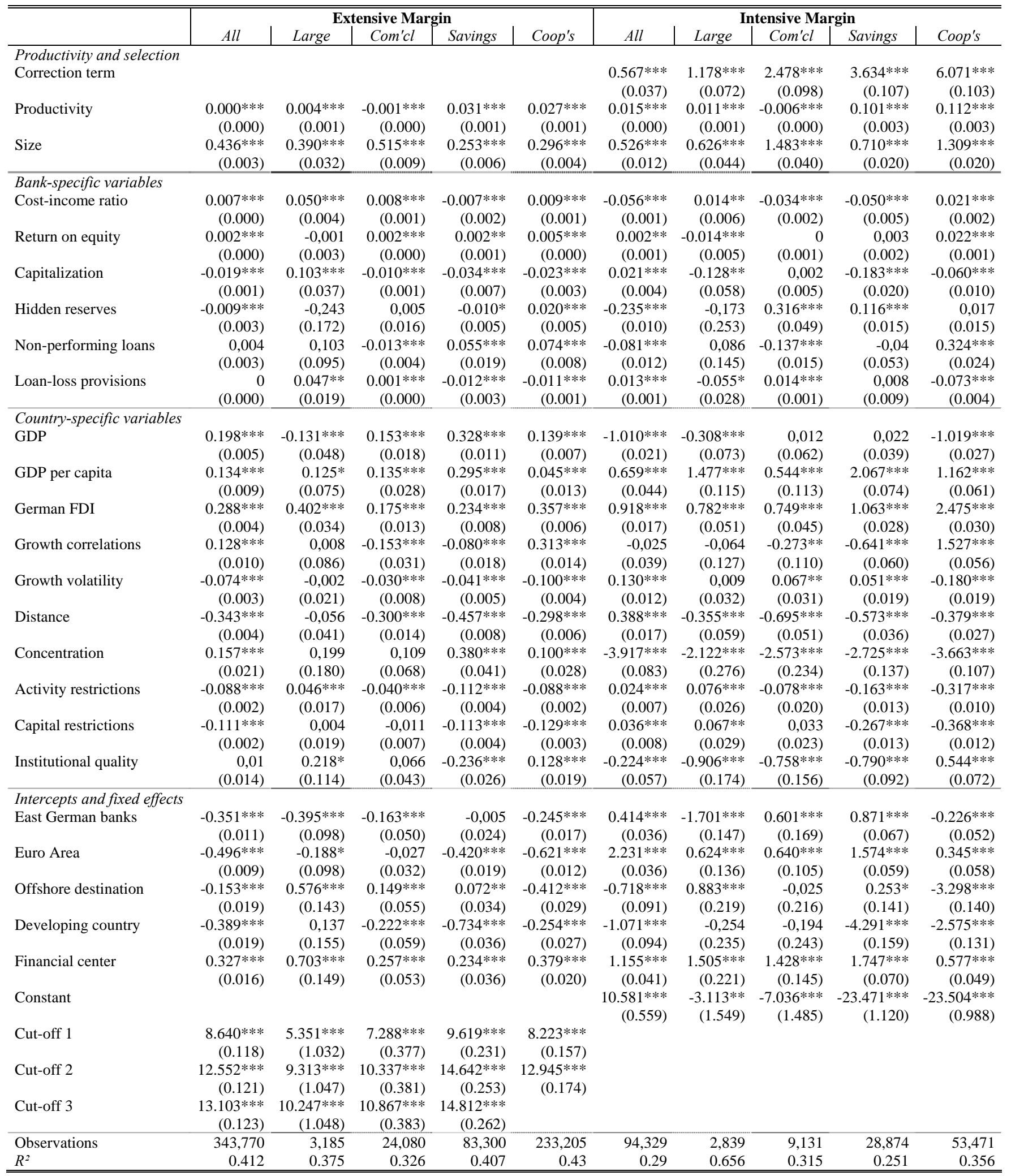

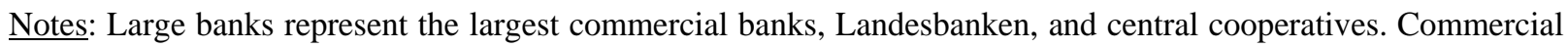
banks are privately owned banks; savings and cooperative banks are regionally operating small banks, owned either mutually or by (regional) governments. The selection equation (Extensive Margin) is estimated as an ordered probit model and includes unreported dummies for banking groups as exclusion restrictions. The dependent variable is the mode of foreign presence. The primary equation (Intensive Margin) is estimated with OLS. The dependent variable is the log volume of international assets. Time-fixed effects are included but not reported. The sample spans the period 2002 to 2006. Productivity is obtained with the method proposed by Levinsohn and Petrin (2003). For further variable descriptions, see the Data Appendix. ***Significant at $1 \%$ level. **Significant at 5\% level. * Significant at $10 \%$ level. 
Figure 1: Volumes of Investment

(a) Total Volume

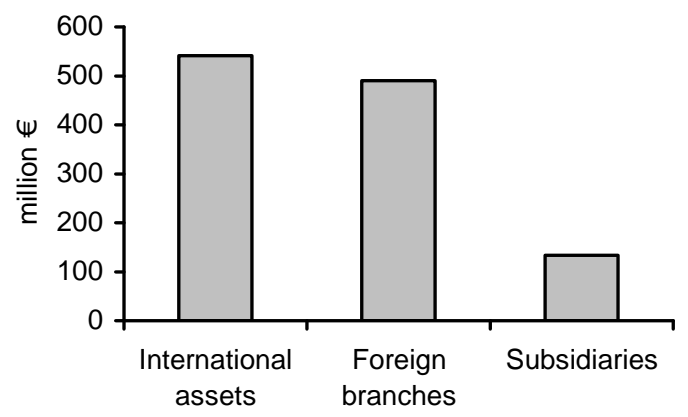

(b) Mean Volume

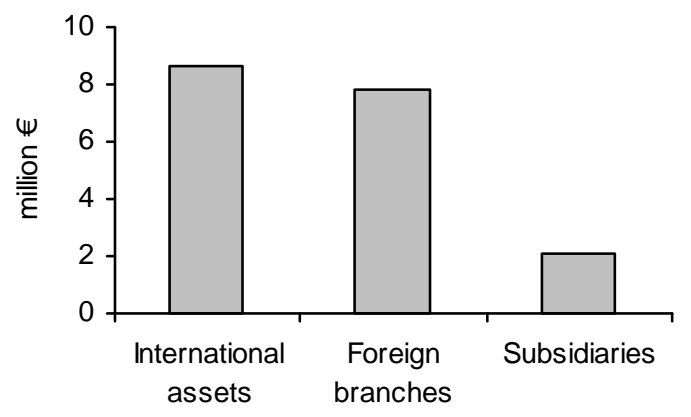

Notes: Total volume is in million $€$ and indicates the total international assets of all banks in a specific Mode, aggregated across countries. Mode 1 (International assets), Mode 2a (Foreign branches), and Mode 2b (Branches and subsidiaries), aggregated across countries. Mean volume is in million $€$ and gives the mean international assets of banks. 


\section{CESifo Working Paper Series}

for full list see www.cesifo-group.org/wp

(address: Poschingerstr. 5, 81679 Munich, Germany, office@cesifo.de)

2829 Rainald Borck and Martin Wimbersky, Political Economics of Higher Education Finance, October 2009

2830 Torfinn Harding and Frederick van der Ploeg, Is Norway's Bird-in-Hand Stabilization Fund Prudent Enough? Fiscal Reactions to Hydrocarbon Windfalls and Graying Populations, October 2009

2831 Klaus Wälde, Production Technologies in Stochastic Continuous Time Models, October 2009

2832 Biswa Bhattacharyay, Dennis Dlugosch, Benedikt Kolb, Kajal Lahiri, Irshat Mukhametov and Gernot Nerb, Early Warning System for Economic and Financial Risks in Kazakhstan, October 2009

2833 Jean-Claude Trichet, The ECB's Enhanced Credit Support, October 2009

2834 Hans Gersbach, Campaigns, Political Mobility, and Communication, October 2009

2835 Ansgar Belke, Gunther Schnabl and Holger Zemanek, Real Convergence, Capital Flows, and Competitiveness in Central and Eastern Europe, October 2009

2836 Bruno S. Frey, Simon Luechinger and Alois Stutzer, The Life Satisfaction Approach to Environmental Valuation, October 2009

2837 Christoph Böhringer and Knut Einar Rosendahl, Green Serves the Dirtiest: On the Interaction between Black and Green Quotas, October 2009

2838 Katarina Keller, Panu Poutvaara and Andreas Wagener, Does Military Draft Discourage Enrollment in Higher Education? Evidence from OECD Countries, October 2009

2839 Giovanni Cespa and Xavier Vives, Dynamic Trading and Asset Prices: Keynes vs. Hayek, October 2009

2840 Jan Boone and Jan C. van Ours, Why is there a Spike in the Job Finding Rate at Benefit Exhaustion?, October 2009

2841 Andreas Knabe, Steffen Rätzel and Stephan L. Thomsen, Right-Wing Extremism and the Well-Being of Immigrants, October 2009

2842 Andrea Weber and Christine Zulehner, Competition and Gender Prejudice: Are Discriminatory Employers Doomed to Fail?, November 2009

2843 Hadi Salehi Esfahani, Kamiar Mohaddes and M. Hashem Pesaran, Oil Exports and the Iranian Economy, November 2009 
2844 Ruediger Bachmann and Christian Bayer, Firm-Specific Productivity Risk over the Business Cycle: Facts and Aggregate Implications, November 2009

2845 Guglielmo Maria Caporale, Burcu Erdogan and Vladimir Kuzin, Testing for Convergence in Stock Markets: A Non-Linear Factor Approach, November 2009

2846 Michèle Belot and Jan Fidrmuc, Anthropometry of Love - Height and Gender Asymmetries in Interethnic Marriages, November 2009

2847 Volker Nitsch and Nikolaus Wolf, Tear Down this Wall: On the Persistence of Borders in Trade, November 2009

2848 Jan K. Brueckner and Stef Proost, Carve-Outs Under Airline Antitrust Immunity, November 2009

2849 Margarita Katsimi and Vassilis Sarantides, The Impact of Fiscal Policy on Profits, November 2009

2850 Scott Alan Carson, The Relationship between Stature and Insolation: Evidence from Soldiers and Prisoners, November 2009

2851 Horst Raff and Joachim Wagner, Intra-Industry Adjustment to Import Competition: Theory and Application to the German Clothing Industry, November 2009

2852 Erkki Koskela, Impacts of Labor Taxation with Perfectly and Imperfectly Competitive Labor Markets under Flexible Outsourcing, November 2009

2853 Cletus C. Coughlin and Dennis Novy, Is the International Border Effect Larger than the Domestic Border Effect? Evidence from U.S. Trade, November 2009

2854 Johannes Becker and Clemens Fuest, Source versus Residence Based Taxation with International Mergers and Acquisitions, November 2009

2855 Andreas Hoffmann and Gunther Schnabl, A Vicious Cycle of Manias, Crashes and Asymmetric Policy Responses - An Overinvestment View, November 2009

2856 Xavier Vives, Strategic Supply Function Competition with Private Information, November 2009

2857 M. Hashem Pesaran and Paolo Zaffaroni, Optimality and Diversifiability of Mean Variance and Arbitrage Pricing Portfolios, November 2009

2858 Davide Sala, Philipp J.H. Schröder and Erdal Yalcin, Market Access through Bound Tariffs, November 2009

2859 Ben J. Heijdra and Pim Heijnen, Environmental Policy and the Macroeconomy under Shallow-Lake Dynamics, November 2009

2860 Enrico Spolaore, National Borders, Conflict and Peace, November 2009 
2861 Nina Czernich, Oliver Falck, Tobias Kretschmer and Ludger Woessmann, Broadband Infrastructure and Economic Growth, December 2009

2862 Evžen Kočenda and Martin Vojtek, Default Predictors and Credit Scoring Models for Retail Banking, December 2009

2863 Christian Gollier and Martin L. Weitzman, How Should the Distant Future be Discounted when Discount Rates are Uncertain?, December 2009

2864 Tiberiu Dragu and Mattias Polborn, Terrorism Prevention and Electoral Accountability, December 2009

2865 Torfinn Harding and Beata Smarzynska Javorcik, A Touch of Sophistication: FDI and Unit Values of Exports, December 2009

2866 Matthias Dischinger and Nadine Riedel, There's no Place like Home: The Profitability Gap between Headquarters and their Foreign Subsidiaries, December 2009

2867 Andreas Haufler and Frank Stähler, Tax Competition in a Simple Model with Heterogeneous Firms: How Larger Markets Reduce Profit Taxes, December 2009

2868 Steinar Holden, Do Choices Affect Preferences? Some Doubts and New Evidence, December 2009

2869 Alberto Asquer, On the many Ways Europeanization Matters: The Implementation of the Water Reform in Italy (1994-2006), December 2009

2870 Choudhry Tanveer Shehzad and Jakob De Haan, Financial Reform and Banking Crises, December 2009

2871 Annette Alstadsæter and Hans Henrik Sievertsen, The Consumption Value of Higher Education, December 2009

2872 Chris van Klaveren, Bernard van Praag and Henriette Maassen van den Brink, Collective Labor Supply of Native Dutch and Immigrant Households in the Netherlands, December 2009

2873 Burkhard Heer and Alfred Maußner, Computation of Business-Cycle Models with the Generalized Schur Method, December 2009

2874 Carlo Carraro, Enrica De Cian and Massimo Tavoni, Human Capital Formation and Global Warming Mitigation: Evidence from an Integrated Assessment Model, December 2009

2875 André Grimaud, Gilles Lafforgue and Bertrand Magné, Climate Change Mitigation Options and Directed Technical Change: A Decentralized Equilibrium Analysis, December 2009

2876 Angel de la Fuente, A Mixed Splicing Procedure for Economic Time Series, December 2009 
2877 Martin Schlotter, Guido Schwerdt and Ludger Woessmann, Econometric Methods for Causal Evaluation of Education Policies and Practices: A Non-Technical Guide, December 2009

2878 Mathias Dolls, Clemens Fuest and Andreas Peichl, Automatic Stabilizers and Economic Crisis: US vs. Europe, December 2009

2879 Tom Karkinsky and Nadine Riedel, Corporate Taxation and the Choice of Patent Location within Multinational Firms, December 2009

2880 Kai A. Konrad, Florian Morath and Wieland Müller, Taxation and Market Power, December 2009

2881 Marko Koethenbuerger and Michael Stimmelmayr, Corporate Taxation and Corporate Governance, December 2009

2882 Gebhard Kirchgässner, The Lost Popularity Function: Are Unemployment and Inflation no longer Relevant for the Behaviour of Germany Voters?, December 2009

2883 Marianna Belloc and Ugo Pagano, Politics-Business Interaction Paths, December 2009

2884 Wolfgang Buchholz, Richard Cornes and Dirk Rübbelke, Existence and Warr Neutrality for Matching Equilibria in a Public Good Economy: An Aggregative Game Approach, December 2009

2885 Charles A.E. Goodhart, Carolina Osorio and Dimitrios P. Tsomocos, Analysis of Monetary Policy and Financial Stability: A New Paradigm, December 2009

2886 Thomas Aronsson and Erkki Koskela, Outsourcing, Public Input Provision and Policy Cooperation, December 2009

2887 Andreas Ortmann, "The Way in which an Experiment is Conducted is Unbelievably Important": On the Experimentation Practices of Economists and Psychologists, December 2009

2888 Andreas Irmen, Population Aging and the Direction of Technical Change, December 2009

2889 Wolf-Heimo Grieben and Fuat Şener, Labor Unions, Globalization, and Mercantilism, December 2009

2890 Conny Wunsch, Optimal Use of Labor Market Policies: The Role of Job Search Assistance, December 2009

2891 Claudia Buch, Cathérine Tahmee Koch and Michael Kötter, Margins of International Banking: Is there a Productivity Pecking Order in Banking, too?, December 2009 